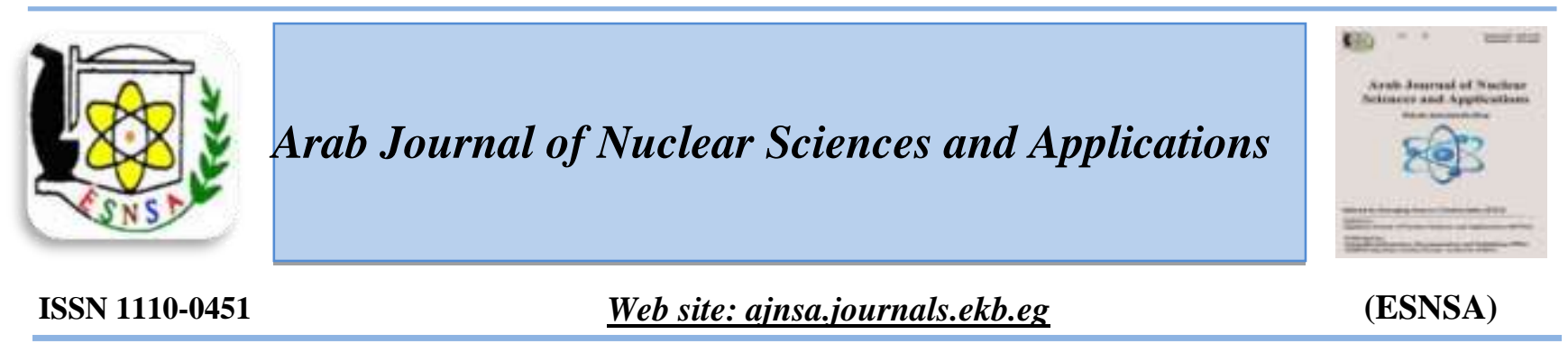

\title{
Insight on Radiological Risk Assessment and its Statistical Evaluations for Abu Dabbab Albite Granite Mining Area, Central Nubian Shield, Egypt
}

\author{
M.Th.S. Heikal ${ }^{(1)} *$, S.R.Gomaa ${ }^{(2)}$, Mohamed Abd El Monsef ${ }^{(1)}$, A.A. Taha ${ }^{(3)}$, G. Top ${ }^{(4) *}$, K.R., Mahmoud ${ }^{(5)}$, \\ M.M. El- Mansi ${ }^{(6)}$ \\ ${ }^{1}$ Geology Department, Faculty of Science, Tanta University, Egypt \\ ${ }^{2}$ Sinotharwa Drilling Company, Cairo \\ ${ }^{3}$ Nuclear and Radiological Regulatory Authority, Egypt \\ ${ }^{4}$ Istanbul Technical University (ITU), Eurasia Institute of Earth Sciences, Istanbul, Turkey \& Szent Istvan University \\ (SZIE), Chemistry Department, PhD School of Environmental Sciences, Gödöllö, Hungary \\ ${ }^{5}$ Physics Department, Faculty of Science, Kafr El Sheikh University, Egypt \\ ${ }^{6}$ Nuclear Materials Authority, Egypt
}

Received $28^{\text {th }}$ April 2018 Accepted $1^{\text {st }}$ July 2018

\begin{abstract}
The deals with the determination of the possible radiological risks by the help of internationally approved health hazard addressed by field and laboratory gamma measurements performed for surface, adit and core samples from Gabal Abu Dabbab albite granite Ta-Nb-Sn mining area. The studied area is located some $50 \mathrm{~km}$ northwestern Marsa Alam city within the central Nubian Shield of Egypt. The field measurements were taken by portable RS-230 $\gamma$-ray spectrometer and the laboratory spectrometric analyzes were verified by HPGe detector for the radioactivity measurements of ${ }^{238} \mathrm{U},{ }^{226} \mathrm{Ra}$, ${ }^{232} \mathrm{Th}$ and ${ }^{40} \mathrm{~K}$ $(\mathrm{Bq} / \mathrm{kg})$ in the studied samples to assess their radiation hazards. Statistical depicting groups, summary statistics and two sample comparison tests (t-test and Mann-Whitney test) were used for statistical evaluations. The gamma-ray radioactivitylevels of surface samples reached 94.68, 61.64, 45.10 and $1051.62 \mathrm{~Bq} / \mathrm{kg}$ for ${ }^{238} \mathrm{U},{ }^{226} \mathrm{Ra},{ }^{232} \mathrm{Th}$ and ${ }^{40} \mathrm{~K}$ respectively, whereas adit samples reached 206.47, 113.16, 198.7, 939.43 Bq/kg and core samples reach to $108.23,54.17,43.47,939.42$ respectively. Almost values of the radiation hazard indices in the studied samples were under the health hazard limits.
\end{abstract}

Keywords: Abu Dabbab albite granite, centralNubian Shield, Egypt, natural radioactivity- RS-230 \& HPGe spectroscopy, statistical analysis, radiological risk assessment

\section{Introduction}

Radiobiological and radioecological hazard problems emanating from the thriving mining activities throughout the world are one of the major topics taken into account by the regulatory body of different states [1-4]. Potential pathways of human exposure to radiation from mining areas occur in many ways namely external gamma radiation from mines, inhalation of radionuclides containing dust, usage of contaminated drinking water and ingestion of radionuclides through the

food chain [5-6]. Partial uptake and deposition, retention half-times in body, food and other environmental compartments, and decay properties are the parameters in terms of radiology that help to estimate the exposed dose [7-8].

In terms of radiation protection, ${ }^{238}$ Uand ${ }^{232} \mathrm{Th}$ decay series and ${ }^{40} \mathrm{~K}$ a non-series radionuclide has a significant role, therefore, their activity concentrations are crucial in the estimation of radiological hazard [9]. Natural and artificial

Corresponding author: Mohamed.hekal1@science.tanta.edu.eg

DOI: 10.21608 /ajnsa.2018.3686.1086

(C) Scientific Information, Documentation and Publishing Office (SIDPO)-EAEA 
factors can provoke their dispersion from mining sites and they may threaten the surrounding communities by long-acting effects [10-12].

It is known that some REE ore deposits are rich in $\mathrm{U}$ and/or Th because of mineralization processes. Due to that reason, NORM (naturally occurring radioactive material) issue has been integrated into rare earth elements (REEs) related safety requirements to reduce radiation exposure [13-16]. Re-mineralization of the radioactive elements within shear zones causes a higher level of radioactivity [17-19]. Moreover, strain-correlated fracturing that happens in the zones may induce differential element mobility, redistribution and size changing of the radioactive minerals.

As an example, in zircon minerals which is the main mineral to examine due to many geoscience disciplines, $\mathrm{U}-\mathrm{Pb}$ isotopic systems may be damaged by $\mathrm{Pb}$ loss, $\mathrm{U}$ gain and size reductions/increases of the minerals in shear zones. Following micro-fracturing may occur at the Urich zones due to the alpha-damage [20-21].

Radiological hazards due to long-term exposure to the radiation emitting from granites also have been determined by many authors $[17,19,22-28]$.

Measurements were performed by different techniques of spectroscopic methods including a portable RS-230 spectrometer and Hyper Purity Germanium (HPGe) detector. In this study, not only surface samples, but also underground core samples at different depths were evaluated to show the dissimilarity of their radioactivity levels and potential health hazards. For data analysis and evaluations, summary statistics, statistical depicting groups such as box and whisker diagrams, scatter plots, two sample comparison tests (t-test and Mann-Whitney test) were used. As a result, possible radiation hazards arising from naturally occurring radionuclides in the study area were evaluated by the help of internationally approved health hazard indices [5, 14, 29-33].

\section{Geologic setting}

Abu Dabbab area is located some $50 \mathrm{~km}$ to the northwest from Marsa Alam city (Figure1) covering about $2 \mathrm{~km}^{2}$. It includes Gabal Abu Dabbab albite granite $\left(0.4 \mathrm{~km}^{2}, 450 \mathrm{~m}\right.$ above sea level) that intrudes into ophiolitic mélange (exotic blocks of serpentinites, metavolcanics and metasediments, Figure1).

The studied area is mainly sheared (Figure2A-B) by cross-cutting faults and shear zones trending along NNW-SSE and dissected by quartz and amazonite veins as well as felsic-basic dykes (Figure1 \& Figure2C-D).

Field radiometric investigation and measurements have been performed at different sites from surface outcrops, adit opening points and across shear zones cut amazonite veins of Abu Dabbab albite granite (Table 1).

\section{Materials and Methods}

In this study, Abu Dabbab albite granite Ta-Nb-Sn mining area was chosen as a study area to determine its radiological effects. It has attracted many investigators for being most important raremetal mining area in the central Nubian Shield of Egypt [34-39]. The Gabal Abu Dabbab rare metals-bearing albite granite represents one of the Late Pan-African alkaline plutons of granitic rocks (650-570 Ma) [40]. Marsa Alam area of the central Nubian Shield of Egypt, which is located to the southeast from Abu Dabbab area, embraces many mineral resources such as gold (El-Sukari Gold Mine) and Ta-Nb-Sn (Abu Dabbab Mine).

Abu Dabbab albite granite forms low to moderate hills $(170-450 \mathrm{~m})$ and is characterized by enrichment of tin mineralization and rare-metals profit. It constitutes a unique stock-like intrusion with off-shoots in the form of elephant's trunk to the northwest of the stock (Figure1). The studied stock is flanked by mafic and felsic dykes to the south and east of the studied area. Numerous quartz veins and amazonite veins trend more or less in NE and NW and associated mostly with tantalite, columbite and tin mineralization. As for the structural framework of Abu Dabbab albite granite and its country rocks of ophiolitic mélange, they are bounded by N-S, NW and NNE trending shear zones (Figure1). At the southern end on both ophiolitic mélange and albite granite, the shear zones, quartz and amazonite tension veins are well presented (Figure2C). These shears continue further north and are confined to the contact zones at the marginal parts of the albite granite outcrop. The main components of the shear zone are highly deformed granite sheets tend to be mylonitic fashion (Figure2A). 


\section{Ground Spectrometric Survey}

Field gamma spectrometric measurements were performed at 21 stations of different sites (Table $1 \& 5$ and Figure 3 ) for surface and adit outcrops as well as across shear zones within amazonite veins in Abu Dabbab albite granite using a RS-230 BGO Super-Spec model portable detector (Figure2A-B) and handheld spectrometer survey meter unit in 95\% relative efficiency (Figure2A-B). This detector has full assay capability for data of $\mathrm{K} \%$, $\mathrm{eU}(\mathrm{ppm})$ and eTh (ppm). For proper operation, it was manufactured by an independent private company (Radiation Solutions, Inc., $386 \mathrm{~W}$ at line Ave, Mississauga, Ontario, Canada, L4Z 1X2). The term 'equivalent' or its abbreviation ' $\mathrm{e}$ ' is used to indicate that the equilibrium is assumed between the radioactive daughter isotopes monitored by the spectrometer and their respective parent isotope.

\section{Sample Preparation}

Surface, adit and subsurface core samples (200$230 \mathrm{~m}$ at depth, Tantalum-Egypt Company) were carefully collected from Abu Dabbab albite granite to represent the entire $\mathrm{Ta}-\mathrm{Nb}-\mathrm{Sn}$ mining area (Figure1 [37, 56]). The samples, approximately $200 \mathrm{~g}$ each were neatly packed into a well-labeled polyethylene bag, and transported to the Nuclear and Radiological Regulatory Authority in Cairo for analysis at the radiation protection laboratory. The samples were oven-dried at a temperature of $100^{\circ}$ $\mathrm{C}$ for 72 hours. Thesieved (200 mesh), then dried samples were pulverized and $185 \pm 10 \mathrm{~g}$ of the homogenized samples were carefully packed into labeled Marinelli beakers and properly sealed to prevent the escape of radon. The sealed samples were stored for about five weeks to attain radiological (secular) equilibrium where the decay rates of the daughter nuclides and their respective parents become equal [22, 41-43].

\section{Petrographic inspection}

The microscopic studies allow investigating the petrographic and mineralogical characteristics of the main rock types of albite granite (Figure4A-D). In spite of its small size, a variation in the textural relationship, an abundance of accessory minerals and degree of deformation is evident at Gabal Abu Dabbab albite granites. Granularityof the rock is generally ineqigranular, fine to medium-grained found invariety of colors including grayish white to vivid white. Cataclasis occurs due to in the order of locally well-developed intense brecciation, deformation and silicification these particularly with their shear zones within albite granite and ophiolitic mélange. Based on these features, the granite of Gabal Abu Dabbab can be broadly grouped into massive albite granite and deformed albite granite (Cataclasites).

Massive albite granite consists of albite, quartz and microcline. Accessory and opaque minerals are found in relatively abundant quantities and form about about 5 to 10 rock modal composition. Plagioclase feldspar mineral of albite composition $\left(\mathrm{An}_{5}-\mathrm{An}_{10}\right)$ is the dominant mineral with an average of $45 \%$ (in few samples it decreases to $30 \%$ ). The albite laths exhibit interpenetrating and interlocking (snowball texture, Figure4A).

Deformed albite granite is mineralogically similar to the massive albite granite, but it is characterized by high deformation, silicification and less abundant accessory minerals. Granules of the rock is ineqigranular, fine to medium-grained, with porphyroclastic texture (Figure4B). Zircon, sphene, apatite and tantalite-columbite are the main accassories (Figure4C-D) for both two rock types.

\section{Gamma-ray spectroscopy Activity measurements}

Activity measurements were performed by a gamma-ray spectrometer at the Egyptian Nuclear and Radiological Regulatory Authority, Radiation Protection Laboratory using a vertical HPGe detector of $40 \%$ relative efficiency and full width at half maximum (FWHM) of $2.0 \mathrm{keV}$ for ${ }^{60} \mathrm{Co}$ gamma energy line at $1332 \mathrm{keV}$. The detector was operated with Canberra Genie 2000 software for gamma acquisition and analysis. The HPGe detector was contained 4 inches thick low background lead shield for germanium detectors in freestanding lead providing a low background environment to shield the detector from lead fluorescent X-rays and bremsstrahlung, the lead is lined with $1 \mathrm{~mm}$ tin and $1.6 \mathrm{~mm}$ copper layer. 


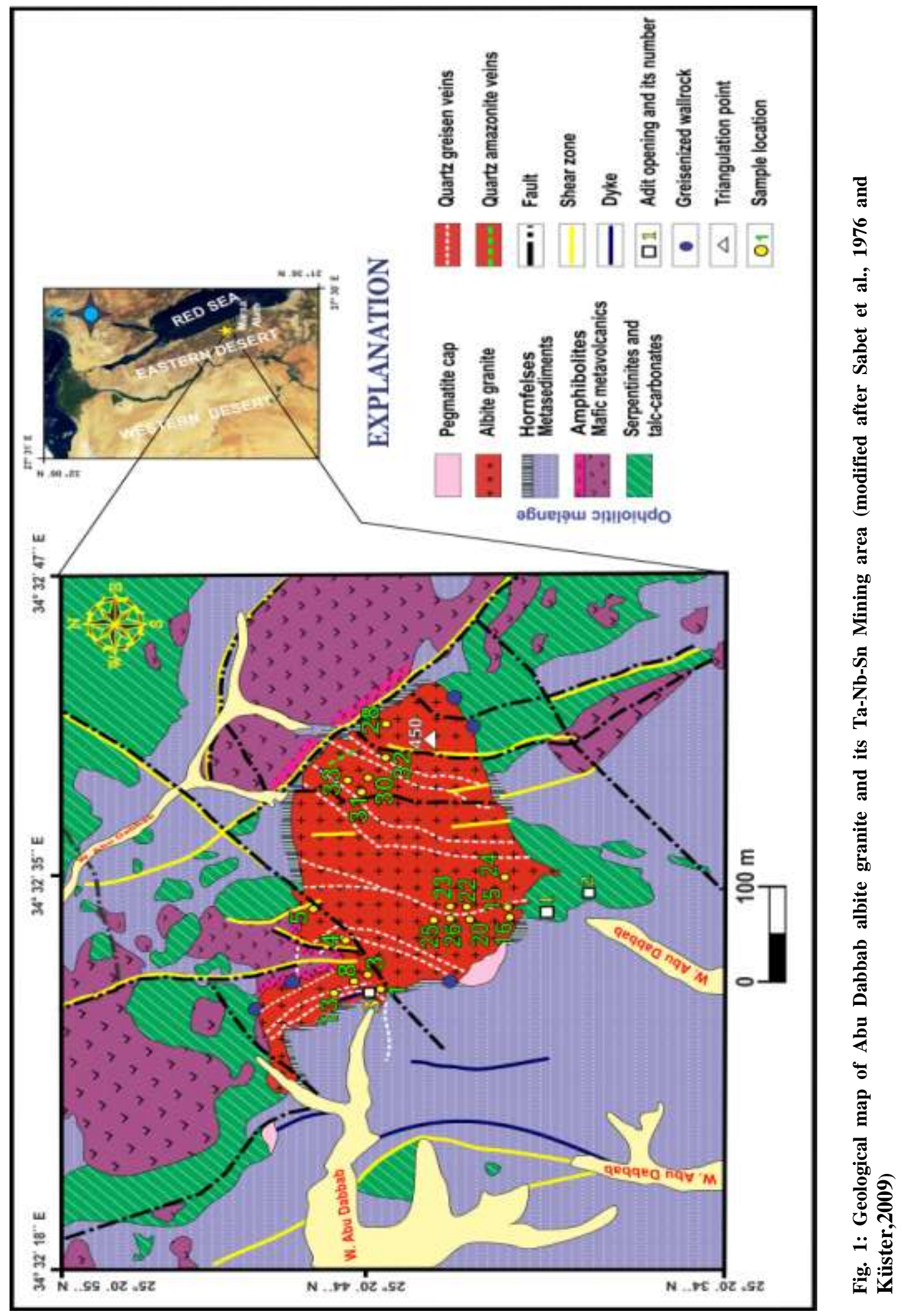




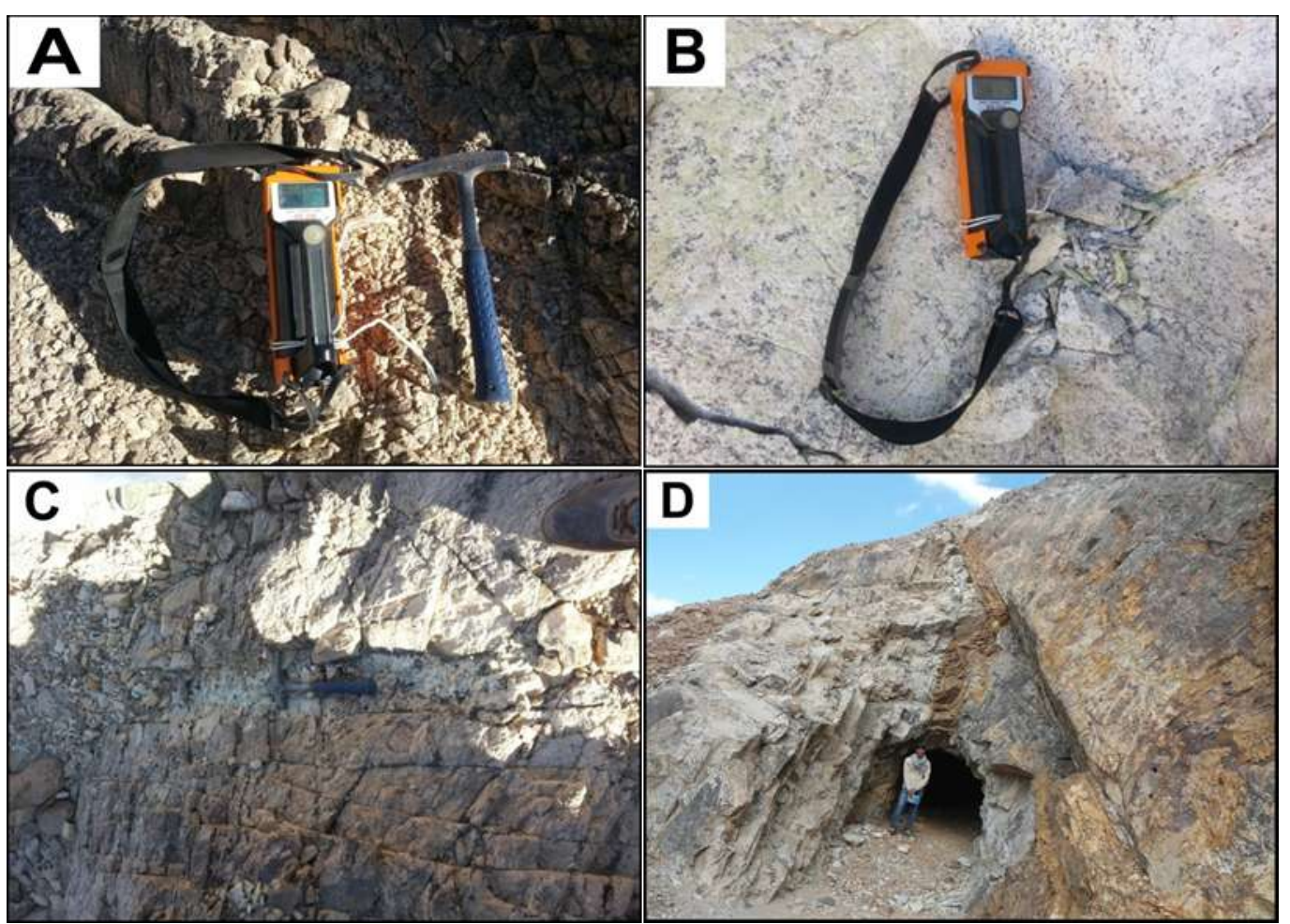

Figure(2): A. Close-up view of deformed albite granite showing tensional shearing trending NNW, B. Close-up view of massive albite granite, Portable RS-230 as a scale, C. Amazonite vein cross cuts sheared albite granite, D. Adit entrance \#3 in albite granite. Note a twisted basaltic dike cross cuts the sheared granite

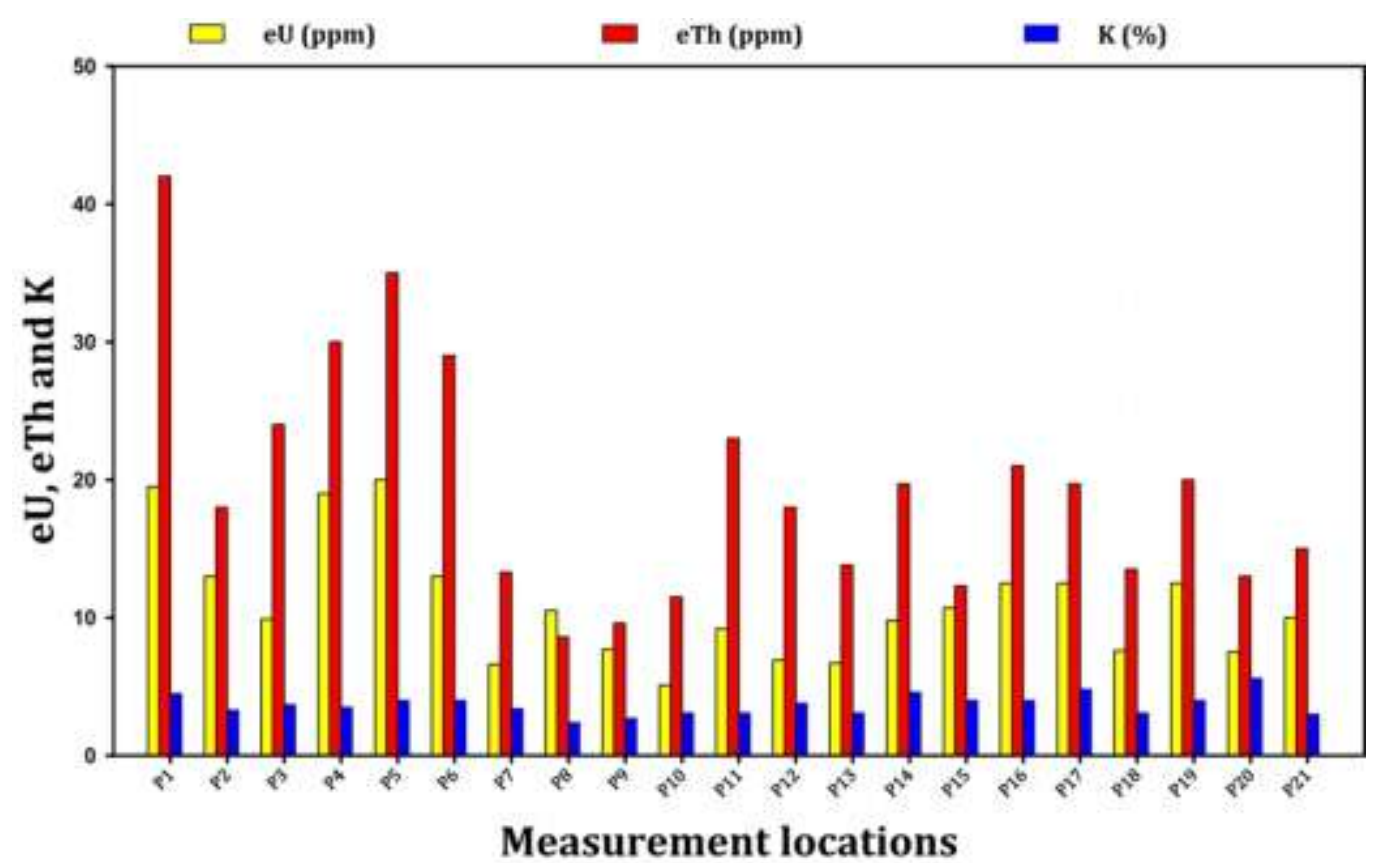

Figure(3): Histogram for ground spectrometric measurements of eU (ppm), eTh (ppm), K (\%) using RS-230 spectrometer forsurface exposure, and adit samples of Abu Dabbab albite granite. For explanation, refer to Table 1 
Table (1): Ground gamma-ray spectrometric measurements (K. eU and eTh) for Abu Dabbab albite granite using RS-230 spectrometer

\begin{tabular}{|c|c|c|c|c|c|}
\hline Points & $\begin{array}{c}K \\
(\%)\end{array}$ & $\begin{array}{c}\mathbf{e U} \\
(\mathbf{p p m})\end{array}$ & $\begin{array}{c}\text { eTh } \\
(\mathbf{p p m})\end{array}$ & Latitude - Longitude & Remarks \\
\hline P1 & 4.5 & 19.5 & 42.0 & $\begin{array}{c}25^{\circ} 20^{\prime} 43.72^{\prime \prime} \mathrm{N}-34^{\circ} 32^{\prime} \\
30.65^{\prime \prime} \mathrm{E}\end{array}$ & $\begin{array}{l}\text { Sheared Granite- } \\
\text { Left side of Adit } \\
\# 3\end{array}$ \\
\hline $\mathbf{P 2}$ & 3.3 & 13.0 & 18.0 & $\begin{array}{c}25^{\circ} 20^{\prime} 44.00^{\prime \prime} \mathrm{N}-34^{\circ} 32^{\prime} \\
30.80^{\prime \prime} \mathrm{E}\end{array}$ & $\begin{array}{l}\text { At the Entrance of } \\
\text { Adit \#3(Contact) }\end{array}$ \\
\hline P3 & 3.7 & 9.9 & 24.0 & $\begin{array}{c}25^{\circ} 20^{\prime} 43.70^{\prime \prime} \mathrm{N}-34^{\circ} 32^{\prime} \\
30.55^{\prime \prime} \mathrm{E}\end{array}$ & $\begin{array}{c}\text { Inside of Adit \#3 } \\
\text { (Quarried) }\end{array}$ \\
\hline P4 & 3.5 & 19.0 & 30.0 & $\begin{array}{c}25^{\circ} 20^{\prime} 44.18^{\prime \prime} \mathrm{N}-34^{\circ} 32^{\prime} \\
31.26^{\prime \prime} \mathrm{E}\end{array}$ & $\begin{array}{c}\text { Sheared Granite- } \\
\text { Right side (Away) } \\
\text { of Adit \#3 }\end{array}$ \\
\hline P5 & 4.0 & 20.0 & 35.0 & $\begin{array}{c}25^{\circ} 20^{\prime} 43.90^{\prime \prime} \mathrm{N}-34^{\circ} 32^{\prime} \\
31.00^{\prime \prime} \mathrm{E}\end{array}$ & $\begin{array}{c}\text { Sheared Granite- } \\
\text { Right side (Away) } \\
\text { of Adit \#3 }\end{array}$ \\
\hline P6 & 4.0 & 13.0 & 29.0 & $\begin{array}{c}25^{\circ} 20^{\prime} 43.47^{\prime \prime} \mathrm{N}-34^{\circ} 32^{\prime} \\
31.31^{\prime \prime} \mathrm{E}\end{array}$ & Sheared Granite \\
\hline P7 & 3.4 & 6.6 & 13.3 & $\begin{array}{c}25^{\circ} 20^{\prime} 40.47^{\prime \prime} \mathrm{N}-34^{\circ} 32^{\prime} \\
36.85^{\prime \prime} \mathrm{E}\end{array}$ & Massive Granite \\
\hline P8 & 2.4 & 10.5 & 8.6 & $\begin{array}{c}25^{\circ} 20^{\prime} 39.97^{\prime \prime} \mathrm{N}-34^{\circ} 32^{\prime} \\
36.17^{\prime \prime} \mathrm{E}\end{array}$ & Massive Granite \\
\hline P9 & 2.7 & 7.7 & 9.6 & $\begin{array}{c}25^{\circ} 20^{\prime} 39.70^{\prime \prime} \mathrm{N}-34^{\circ} 32^{\prime} \\
35.74^{\prime \prime} \mathrm{E}\end{array}$ & Massive Granite \\
\hline P10 & 3.1 & 5.1 & 11.5 & $\begin{array}{c}25^{\circ} 20^{\prime} 40.32^{\prime \prime} \mathrm{N}-34^{\circ} 32^{\prime} \\
35.97^{\prime \prime} \mathrm{E}\end{array}$ & Massive Granite \\
\hline P11 & 3.1 & 9.2 & 23.0 & $\begin{array}{c}25^{\circ} 20^{\prime} 39.40^{\prime \prime} \mathrm{N}-34^{\circ} 32^{\prime} \\
35.24^{\prime \prime} \mathrm{E}\end{array}$ & Massive Granite \\
\hline P12 & 3.8 & 6.9 & 18.0 & $\begin{array}{c}25^{\circ} 20^{\prime} 39.70^{\prime \prime} \mathrm{N}-34^{\circ} 32^{\prime} \\
35.15^{\prime \prime} \mathrm{E}\end{array}$ & Massive granite \\
\hline P13 & 3.1 & 6.7 & 13.8 & $\begin{array}{c}25^{\circ} 20^{\prime} 39.69^{\prime \prime} \mathrm{N}-34^{\circ} 32^{\prime} \\
34.84^{\prime \prime} \mathrm{E}\end{array}$ & Massive granite \\
\hline P14 & 4.6 & 9.8 & 19.7 & $\begin{array}{c}25^{\circ} 20^{\prime} 39.88^{\prime \prime} \mathrm{N}-34^{\circ} 32^{\prime} \\
33.96^{\prime \prime} \mathrm{E}\end{array}$ & Massive granite \\
\hline P15 & 4.0 & 10.7 & 12.3 & $\begin{array}{c}25^{\circ} 20^{\prime} 40.11^{\prime \prime} \mathrm{N}-34^{\circ} 32^{\prime} \\
33.40^{\prime \prime} \mathrm{E}\end{array}$ & Massive granite \\
\hline P16 & 4.0 & 12.5 & 21.0 & $\begin{array}{c}25^{\circ} 20^{\prime} 44.88^{\prime \prime} \mathrm{N}-34^{\circ} 32^{\prime} \\
38.88^{\prime \prime} \mathrm{E}\end{array}$ & Massive granite \\
\hline P17 & 4.8 & 12.5 & 19.7 & $\begin{array}{c}25^{\circ} 20^{\prime} 44.61^{\prime \prime} \mathrm{N}-34^{\circ} 32^{\prime} \\
39.16^{\prime \prime} \mathrm{E}\end{array}$ & Massive granite \\
\hline P18 & 3.1 & 7.6 & 13.5 & $\begin{array}{c}25^{\circ} 20^{\prime} 44.00^{\prime \prime} \mathrm{N}-34^{\circ} 32^{\prime} \\
39.62^{\prime \prime} \mathrm{E}\end{array}$ & Massive granite \\
\hline P19 & 4.0 & 12.5 & 20.0 & $\begin{array}{c}25^{\circ} 20^{\prime} 43.59^{\prime \prime} \mathrm{N}-34^{\circ} 32^{\prime} \\
39.81^{\prime \prime} \mathrm{E}\end{array}$ & Massive granite \\
\hline P20 & 5.6 & 7.5 & 13.0 & $\begin{array}{c}25^{\circ} 20^{\prime} 44.72^{\prime \prime} \mathrm{N}-34^{\circ} 32^{\prime} \\
39.58^{\prime \prime} \mathrm{E}\end{array}$ & $\begin{array}{c}\text { Near Amazonite } \\
\text { Vein }\end{array}$ \\
\hline P21 & 3.0 & 10.0 & 15.0 & $\begin{array}{c}25^{\circ} 20^{\prime} 44.60^{\prime \prime} \mathrm{N}-34^{\circ} 32^{\prime} \\
39.78^{\prime \prime} \mathrm{E}\end{array}$ & $\begin{array}{l}\text { Near Amazonite } \\
\text { Vein }\end{array}$ \\
\hline
\end{tabular}



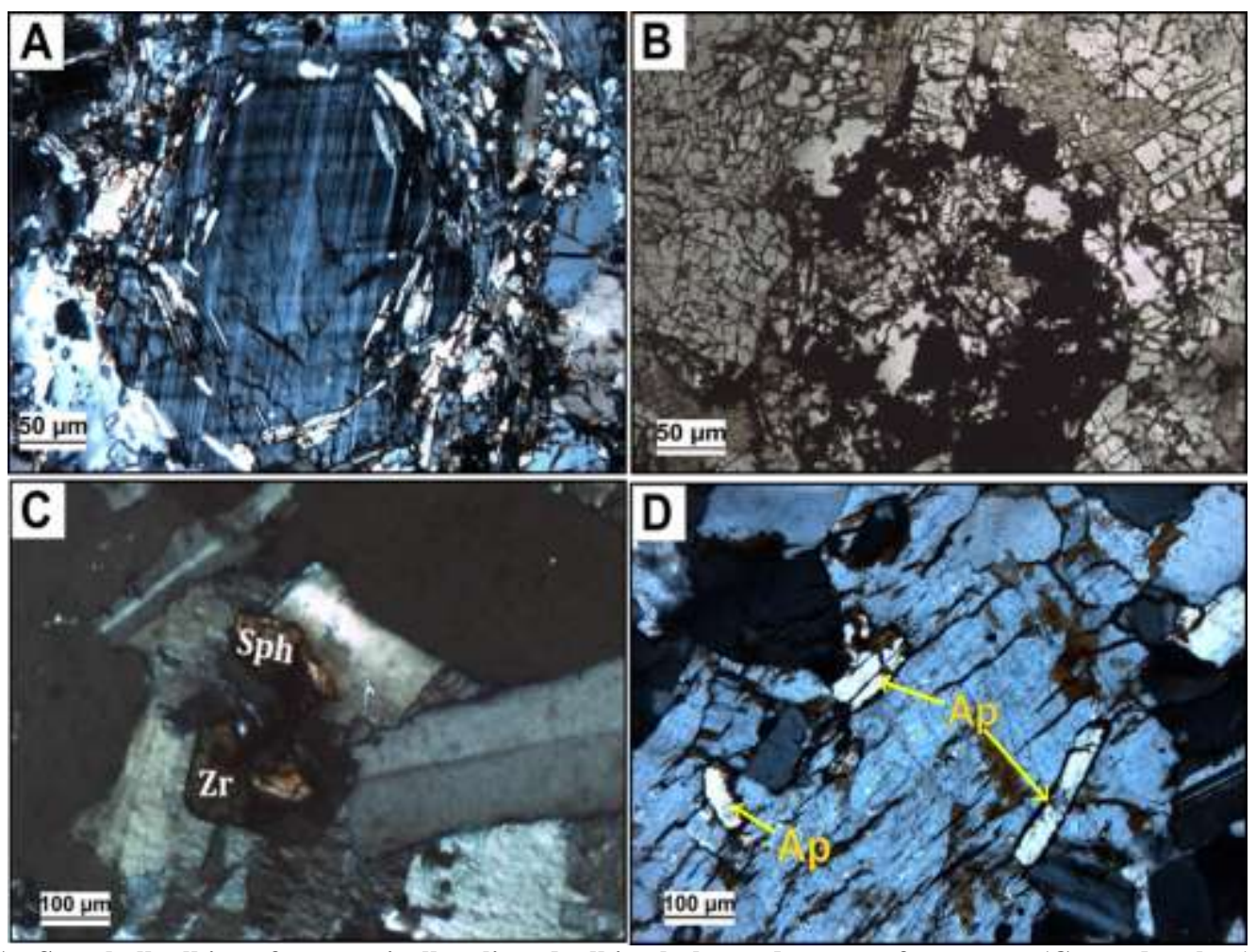

Figure(4): A. Snowball albite of concetrically aligned albite laths and quartz fragments (Crossed polars), B. Highly deformed and streaky quartz and feldspar crystals giving prophyroclastic and mortar textures. Deformed albite granite, PPL, C. Zircon (Zr) and sphene (Sph) accessory minerals in albite granite (crossed polars), D. Bold crystals of apatite (Ap) as inclusions inmega-crystal albite- Massive ablite granite. (Crossed polars), scale bar applies in all photomicrographs

The specific activity calculations of ${ }^{226} \mathrm{Ra}$ and ${ }^{232} \mathrm{Th}$ were obtained indirectly from the gamma rays emitted by their progenies which are in secular equilibrium with them. The determination of ${ }^{226} \mathrm{Ra}$ activity is based upon the detection of $351.9 \mathrm{keV}$ gamma rays emitted by ${ }^{214} \mathrm{~Pb}, 609 \mathrm{keV}$ gamma rays emitted by ${ }^{214} \mathrm{Bi}, 1120 \mathrm{keV}$ gamma rays emitted by ${ }^{214} \mathrm{Bi}, 1764 \mathrm{keV}$ gamma rays emitted by ${ }^{214} \mathrm{Bi}$ and the detection of $295 \mathrm{keV}$ gamma rays emitted by ${ }^{214} \mathrm{~Pb}$. The ${ }^{232} \mathrm{Th}$ activity was determined by the detection of $238.6 \mathrm{keV}$ gamma rays from ${ }^{212} \mathrm{~Pb}, 911.2$ and $969 \mathrm{keV}$ from ${ }^{228} \mathrm{Ac}$ and $583.34 \mathrm{keV}$ gamma rays from ${ }^{208} \mathrm{Tl}$. Activity concentration of ${ }^{40} \mathrm{~K}$ was determined from the $1460.7 \mathrm{keV}$ gamma line. The net area under each photo peak, after background corrections, was used to calculate the activity concentration of each radionuclide in the samples (Table 2 and Figure5). Statistical analyses are given in (Figures $6 \& 12 \mathrm{a}-\mathrm{h}$ and Table 6). The ${ }^{238} \mathrm{U},{ }^{232} \mathrm{Th},{ }^{226} \mathrm{Ra}$ and ${ }^{40} \mathrm{~K}$ average activity concentrations (Bq. $\left.\mathrm{kg}^{-1}\right)$ compared with worldwide average and some literatures [17, 25, 31, 44-47] are given in (Figure 10 and Table $4)$.

\section{Radiological hazard assessment Radium equivalent activity}

The radium equivalent activity, $\mathrm{Ra}_{\mathrm{eq}}$, which is the most widely used radiation hazard index, is a weighted sum of activities of the above three radionuclides based on the assumption that 1 $\mathrm{Bq} / \mathrm{kg}$ of ${ }^{226} \mathrm{Ra}, 0.7 \mathrm{~Bq} / \mathrm{kg}$ of ${ }^{232} \mathrm{Th}$ or $13 \mathrm{~Bq} / \mathrm{kg}$ of ${ }^{40} \mathrm{~K}$ produces the same $\gamma$-ray dose rate and that $\mathrm{Ra}_{\mathrm{eq}}$ should not exceed a maximum of $370 \mathrm{~Bq} / \mathrm{kg}$ [2930], (Table 3). $\mathrm{Ra}_{\mathrm{eq}}$ is given by the following equation [48]:

$\mathrm{Ra}_{\mathrm{eq}}=\mathrm{C}(\mathrm{Ra})+1.43 \times \mathrm{C}(\mathrm{Th})+0.077 \times \mathrm{C}(\mathrm{K}), \quad(1)$ Where $C(\mathrm{Ra}), \mathrm{C}(\mathrm{Th})$ and $\mathrm{C}(\mathrm{K})$ are the specific activity of ${ }^{226} \mathrm{Ra},{ }^{232} \mathrm{Th}$ and ${ }^{40} \mathrm{~K}$, respectively, in $\mathrm{Bq} / \mathrm{kg}$. Statistical analyses are given in (Figure 13 and Table 7). 

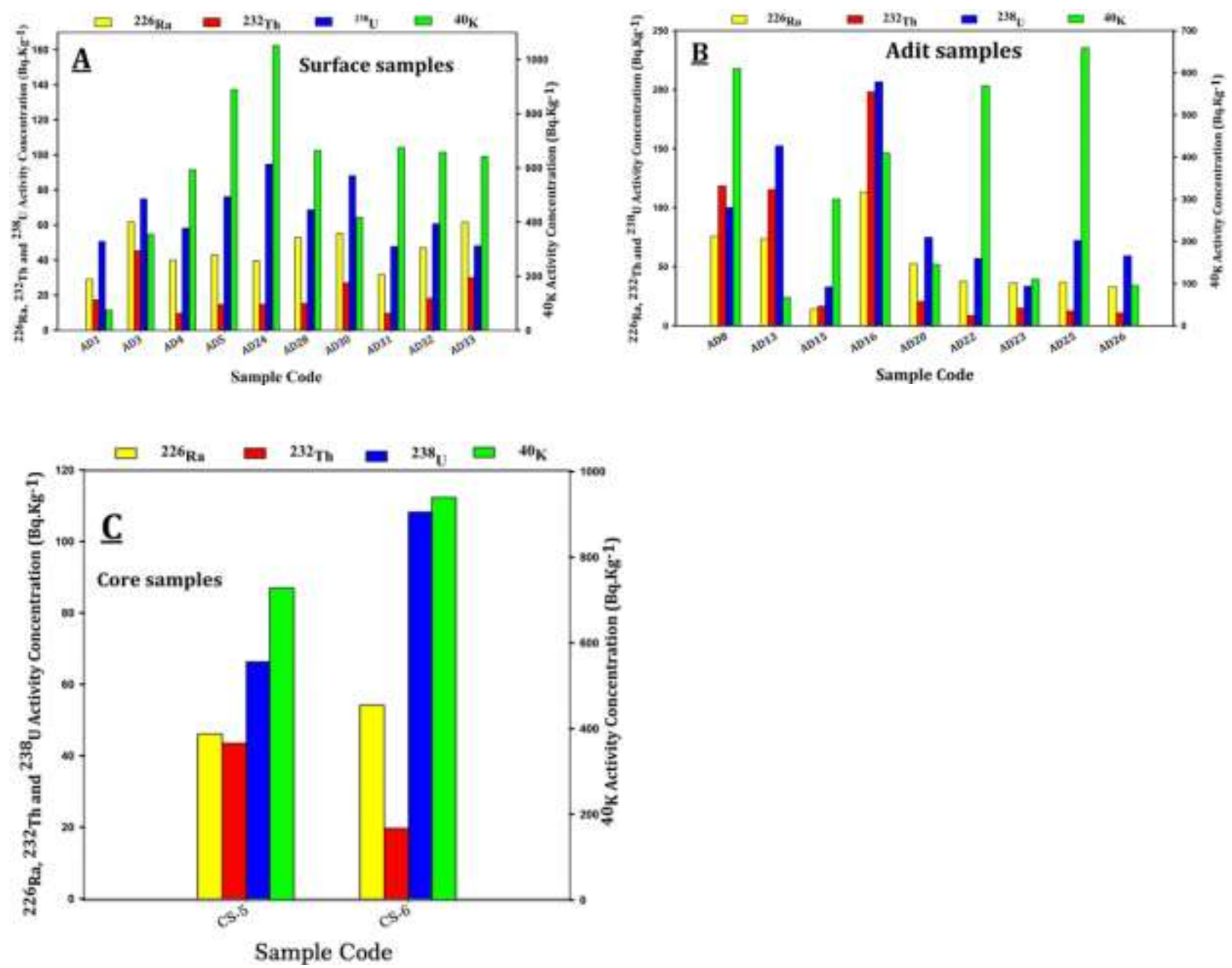

Figure(5): A, B, C Activity concentrations (Bq/kg) of the natural radionuclides $\left({ }^{238} \mathrm{U},{ }^{226} \mathrm{Ra},{ }^{232} \mathrm{Th}\right.$ and $\left.{ }^{40} \mathrm{~K}\right)$ in surface samples, nearby adit and core samples respectively from Abu Dabbab albite granite

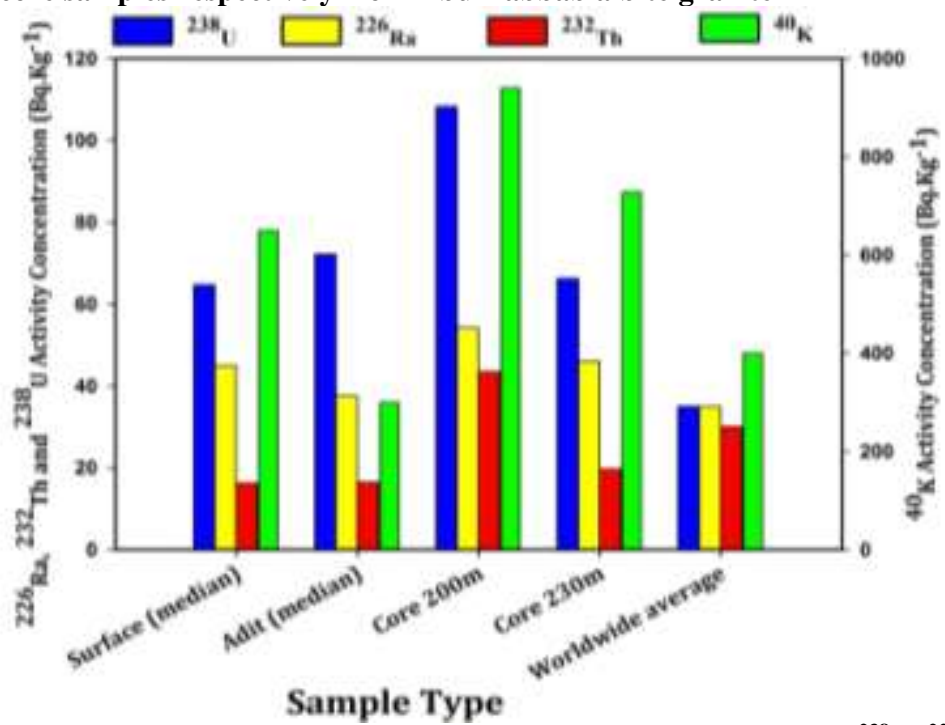

Figure(6): Median values of activity concentrations ( $\mathrm{Bq} / \mathrm{kg}$ ) for the natural radionuclides $\left({ }^{238} \mathrm{U},{ }^{226} \mathrm{Ra},{ }^{232} \mathrm{Th}\right.$ and $\left.{ }^{40} \mathrm{~K}\right)$ of the studied surface, adit and core samples from albite granite in comparison to worldwide average of radionuclides [5] 
Table (2): Specific activity of $\mathrm{C}_{\mathrm{U}} \cdot \mathrm{C}_{\mathrm{Ra}} \cdot \mathrm{C}_{\mathrm{Th}}$ and $\mathrm{C}_{\mathrm{K}}$ of the studied albite granite from Abu Dabbab mining area, Central Eastern Desert, Egypt

\begin{tabular}{|c|c|c|c|c|c|}
\hline $\begin{array}{l}\text { Sample } \\
\text { No. }\end{array}$ & 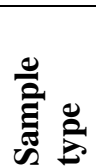 & $\begin{array}{l}\text { Uranium activity } \\
\text { concentration } \\
\mathrm{C}_{\mathrm{U}}(\mathrm{Bq} / \mathrm{kg})\end{array}$ & $\begin{array}{l}\text { Radium activity } \\
\text { concentration } \\
\mathrm{C}_{\mathrm{Ra}}(\mathrm{Bq} / \mathrm{kg})\end{array}$ & $\begin{array}{l}\text { Thorium activity } \\
\text { concentration } \\
\mathrm{C}_{\mathrm{Th}}(\mathrm{Bq} / \mathrm{kg})\end{array}$ & $\begin{array}{l}\text { Potassium } \\
\text { activity } \\
\text { concentration } \\
\mathrm{C}_{\mathrm{K}}(\mathrm{Bq} / \mathrm{kg})\end{array}$ \\
\hline 1 & \multirow{10}{*}{ 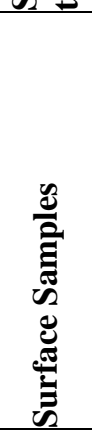 } & 50.59 & 29.00 & 17.25 & 74.25 \\
\hline 3 & & 74.87 & 61.64 & 45.10 & 354.47 \\
\hline 4 & & 58.13 & 39.97 & 9.51 & 593.20 \\
\hline 5 & & 76.09 & 43.00 & 14.53 & 889.32 \\
\hline 24 & & 94.68 & 39.51 & 14.70 & 1051.62 \\
\hline 28 & & 68.62 & 52.96 & 15.13 & 664.74 \\
\hline 30 & & 88.15 & 55.31 & 26.92 & 417.06 \\
\hline 31 & & 47.70 & 31.81 & 9.47 & 675.20 \\
\hline 32 & & 60.64 & 47.00 & 17.96 & 658.34 \\
\hline 33 & & 48.05 & 61.52 & 29.97 & 641.68 \\
\hline 8 & \multirow{9}{*}{ 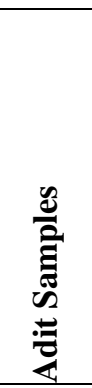 } & 100.09 & 75.79 & 118.42 & 609.49 \\
\hline 13 & & 152.3 & 73.82 & 115.39 & 66.81 \\
\hline 15 & & 32.72 & 14.08 & 16.45 & 300.16 \\
\hline 16 & & 206.47 & 113.16 & 198.07 & 408.89 \\
\hline 20 & & 74.81 & 52.5 & 20.56 & 145.22 \\
\hline 22 & & 56.91 & 37.59 & 8.59 & 569 \\
\hline 23 & & 33.43 & 36.37 & 14.75 & 110.22 \\
\hline 25 & & 72.18 & 36.8 & 12.42 & 659.35 \\
\hline 26 & & 59.16 & 33.01 & 10.8 & 95.36 \\
\hline $\begin{array}{l}\text { CS-5 } \\
200 \mathrm{~m} \\
\text { at } \\
\text { depth }\end{array}$ & \multirow[b]{2}{*}{ ن⿺辶大 } & 66.28 & 46.08 & 43.47 & 728.39 \\
\hline $\begin{array}{l}\text { CS-6 } \\
230 \mathrm{~m} \\
\text { at } \\
\text { depth }\end{array}$ & & 108.23 & 54.17 & 19.6777 & 939.42 \\
\hline
\end{tabular}

\section{External and internal hazard indices}

Another criterion, known as the external hazard index, has been defined in previous studies [29, 48] as:

$$
H_{e x}=\frac{C(R a)}{185}+\frac{C(T h)}{259}+\frac{C(K)}{4810} \leq 1
$$

This index is used to estimate the level of $\gamma$ radiation hazard associated with the external gamma radiation originating from natural radionuclides in the studied samples (Table 3 ).

The internal exposure to radon and its daughter products is quantified by the internal hazard index $\left(H_{\text {in }}\right)$ which is given by the equation [48]:

$H_{\text {in }}=\frac{C(R a)}{185}+\frac{C(T h)}{259}+\frac{C(K)}{4810} \leq 1$

If the maximum concentration of radium is half that of the normal acceptable limit, then $\mathrm{H}_{\mathrm{ex}}$ and $\mathrm{H}_{\text {in }}$ will be less than 1.0 [48]. For the safe use of a material in the construction of dwellings, $\mathrm{H}_{\mathrm{in}}$ should be less than the unity. Statistical analyses were given in (Figures $7 \& 14 a-b$ and Table 8).

Absorbed gamma dose rate

The gamma dose rate in the air is measured at one meter above the ground level and the conversion factors used to calculate the absorbed dose rate are given by equation [47]:

$$
\begin{aligned}
D=0.621 C(T h) & +0.462 C(R a) \\
& +0.0417 C(K)(n G y / h)
\end{aligned}
$$

The terms $\mathrm{C}(\mathrm{Th}), \mathrm{C}(\mathrm{Ra})$ and $\mathrm{C}(\mathrm{K})$ are the average specific activity of ${ }^{232} \mathrm{Th},{ }^{226} \mathrm{Ra}$ and ${ }^{40} \mathrm{~K}$ in $\mathrm{Bq} / \mathrm{kg}$ respectively, and $\mathrm{D}$ is the absorbed gamma dose rate in $\mathrm{nGy} / \mathrm{h}$. Statistical analyses were given in (Figure 15 and Table 9). Additionally, absorbed gamma dose contributors were given in (Figure $19 \mathrm{a}-\mathrm{c})$ 


\section{Annual effective dose rate}

To estimate the annual effective dose rates, the conversion coefficient from the absorbed dose in the air to the effective dose $\left(0.7\right.$ Sv.Gy $\left.{ }^{-1}\right)$ and outdoor occupancy factor $(0.2)$ proposed by [5] are used (Table 3). Therefore, the annual effective dose rate $\left(\mathrm{mSv} \cdot \mathrm{yr}^{-1}\right)$ was calculated by the following formula [5]:

AEDR $\left(\mathrm{mSv} \cdot \mathrm{yr}^{-1}\right)=\mathrm{D}\left(\mathrm{nGy} \cdot \mathrm{h}^{-1}\right) \times 8760 \mathrm{~h} \cdot \mathrm{yr}^{-1} \times$ $0.7 \times\left(10^{3} \mathrm{mSv} / 10^{9}\right) \mathrm{nGy} \times 0.2 \quad(5)$

For indoor measurements (as the case in building materials) the occupancy factor is approximately 0.8 [5] and the equation becomes:

$$
\begin{aligned}
\operatorname{AEDE}_{\text {indoor }}\left(\mathrm{g} \frac{\mathrm{Sv}}{\mathrm{y}}\right) & \\
& =\operatorname{Din}(\mathrm{nGy} / \mathrm{h} \times 8760(\mathrm{~h} / \mathrm{y}) \\
& \times 0.8 \times 0.7(\mathrm{~Sv} / \mathrm{Gy}) \times 10^{-3}
\end{aligned}
$$

For the outdoor the occupancy factor is approximately 0.2 and the equation 7 becomes:

$\operatorname{AEDE}_{\text {out }}\left(\right.$ ? $\left.\frac{\mathrm{Sv}}{\mathrm{y}}\right)=\operatorname{Dout}(\mathrm{nGy} / \mathrm{h} \times 8760(\mathrm{~h} / \mathrm{y}) \times$ $0.2 \times 0.7(\mathrm{~Sv} / \mathrm{Gy}) \times 10-3 \quad(7)$

The world average annual effective dose equivalent (AEDE) from outdoor or indoor terrestrial gamma radiation is $0.48 \mathrm{mSv} /$ year [5]. Statistical analyses were given in (Figures 8 \& 16a-b and Table 10).

\section{Representative gamma index (I $\gamma$ )}

The representative level index, $I \gamma$, is used to evaluate the level of $\gamma$-radiation hazard associated with the natural radionuclides in specific investigated samples, as defined by the following equation [29]:

$$
\mathrm{I} \gamma=\frac{\mathrm{C}(\mathrm{Ra})}{150}+\frac{\mathrm{C}(\mathrm{Th})}{100}+\frac{C(K)}{1500}
$$

This gamma index is also used to correlate the annual dose rate due to the excess external gamma radiation caused by superficial materials (Table 3 ). It is a screening tool for identifying materials that might become of a health concern when used for construction [49]. Values of $\mathrm{I}_{\gamma} \leq 1$ corresponds to an annual effective dose of less than or equal to $1 \mathrm{mSv}$, while $\mathrm{I}_{\gamma} \leq 0.5$ corresponds to annual effective dose less or equal to $0.3 \mathrm{mSv}$ [50]. Statistical analyses were given in (Figures $7 \&$ 17a-b and Table 11).

Outdoor excess lifetime cancer risk (ELCR $\left.{ }_{\text {OUT }}\right)$

The ELCR OUT $_{\text {value demonstrates the number of }}$ extra cancers expected in a given number of people upon exposure to a carcinogen at a given dose (Table 3). Excess lifetime cancer risk (ELCR) is given by the following formula [32]:
ELCRout $=A E D R \times D L \times R F$

Where AEDR is the annual equivalent dose rate, DL is average duration of life (estimated to be 70 years), and RF is the risk factor (S/v), i.e. fatal cancer risk per Sievert. For stochastic effects, ICRP uses RF as 0.05 for the public [32, 54]. Statistical analyses were given in (Figures $9 \& 18 \mathrm{a}-$ $\mathrm{b}$ and Table 12).

\section{Statistical analyses}

Statistical analyses were performed by STATGRAPHICS Centurion XVI and R statistical programs. Depicting groups such as box and whisker diagrams and scatter plots were used to make the outliers and variations noticeable (Figures 11-18). For two sample comparisons t-test and Mann-Whitney W-tests were used for the surface samples (Tables 13 and 14). Tukey's summary statistical analysis [52] was useful in the interpretation of the data.

\section{Discussion}

The results of elemental concentration measurements and potential risk hazard indices calculations were analyzed by Tukey's summary statistics (Exploratory data analysis) [52] and depicted by Box and Whisker plots and scatter plots.

During the field measurements, the authors found that the highest radioactivity levels were up to 20 ppm for eU and $42 \mathrm{ppm}$ for eTh and $5.6 \%$ for K, these value could be attributed to sheared granite nearby adit exposures (P1-P6), whereas low radioactivity levels (P7-P21) were due to massive albite granite near amazonite veins (Figure3 and Table 1) .

For data comparisons, the averages do not give always a meaningful result due to the heterogeneities. As an example, this heterogeneity was especially visible at the Box and Whisker plot of adit samples where the distinction between mean and median is noteworthy.

At a Box and Whisker plot, the range value indicates the extent of variation in data. In the spectrometric measurements, the $\mathrm{C}_{\mathrm{Th}}$ range values of the adit samples (Figure12e) and the $C_{K}$ range values of the surface samples (Figure12g) show the highest variations in distribution probably due to magmatic fractionation. Additionally, in the field measurements, the highest variations were detected for eTh (ppm) values (Figure11a). 


\begin{tabular}{|c|c|c|c|c|c|}
\hline \multicolumn{6}{|c|}{ Table (3): Continued } \\
\hline Sample No. & 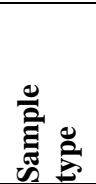 & $\begin{array}{l}\text { AEDR } \\
\text { (mSv/y) } \\
\text { Indoor }\end{array}$ & $\mathbf{H}_{\mathrm{ex}}$ & $\mathbf{H}_{\text {in }}$ & $\begin{array}{lr}\text { Excess life } & \text { time } \\
\text { cancer } & \text { risk } \\
\text { outdoors } & \\
\left(\text { ELCR }_{\text {out }}\right) & \\
\text { x10 }^{-4} & \end{array}$ \\
\hline AD1 & \multirow{10}{*}{ 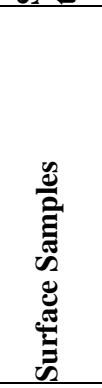 } & 0.13 & 0.16 & 0.24 & 0.13 \\
\hline AD3 & & 0.35 & 0.41 & 0.58 & 0.34 \\
\hline AD4 & & 0.24 & 0.27 & 0.38 & 0.23 \\
\hline AD5 & & 0.32 & 0.36 & 0.47 & 0.31 \\
\hline AD24 & & 0.35 & 0.38 & 0.49 & 0.34 \\
\hline AD28 & & 0.30 & 0.34 & 0.48 & 0.29 \\
\hline AD30 & & 0.29 & 0.34 & 0.49 & 0.28 \\
\hline AD31 & & 0.24 & 0.26 & 0.35 & 0.23 \\
\hline AD32 & & 0.30 & 0.33 & 0.46 & 0.28 \\
\hline AD33 & & 0.36 & 0.42 & 0.58 & 0.35 \\
\hline Average & \multirow{10}{*}{ 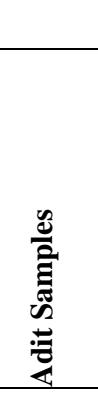 } & 0.288 & 0.327 & 0.452 & 0.278 \\
\hline AD8 & & 0.66 & 0.79 & 0.99 & 0.63 \\
\hline AD13 & & 0.53 & 0.66 & 0.86 & 0.51 \\
\hline AD15 & & 0.14 & 0.16 & 0.20 & 0.14 \\
\hline AD16 & & 0.94 & 1.16 & 1.46 & 0.91 \\
\hline AD20 & & 0.21 & 0.25 & 0.39 & 0.20 \\
\hline AD22 & & 0.23 & 0.25 & 0.35 & 0.22 \\
\hline AD23 & & 0.15 & 0.18 & 0.28 & 0.14 \\
\hline AD25 & & 0.26 & 0.28 & 0.38 & 0.25 \\
\hline AD26 & & 0.13 & 0.15 & 0.24 & 0.12 \\
\hline Average & & 0.36 & 0.43 & 0.57 & 0.35 \\
\hline $\begin{array}{l}\text { CS-5 } \\
200 \text { m at depth }\end{array}$ & \multirow{2}{*}{ ن⿺辶 } & 0.39 & 0.44 & 0.57 & 0.37 \\
\hline $\begin{array}{l}\text { CS-6 } \\
230 \text { m at depth }\end{array}$ & & 0.37 & 0.42 & 0.56 & 0.36 \\
\hline Average & & 0.38 & 0.43 & 0.565 & 0.365 \\
\hline
\end{tabular}

The outliers that were depicted in Box and Whisker plots and given in the following tables may need analysis repetitions. Two-sample comparison tests were used to calculate and determine whether there are statistical differences between the two groups. To understand the correlations between $\mathrm{H}_{\mathrm{ex}}$ and $\mathrm{H}_{\mathrm{in}}$ indices values of the surface samples at the $95 \%$ confidence level, the t-test was used (Table 13). The computed Pvalue was less than 0.05 so for the surface samples the null hypothesis could be rejected and the difference proved between the groups in terms of their mean values for median comparisons MannWhitney W-test were used (Table14). The computed P-value was less than 0.05 for the surface samples so there was a significant difference between the medians at the $95 \%$ confidence level for the surface samples. As a result of the tests, for $\mathrm{H}_{\mathrm{ex}}, \mathrm{H}_{\text {in }}$ indices of the surface samples in terms of mean and median comparisons there was a significant difference. Due to sample number, adit and core samples were not suitable for the comparison tests.

The specific gamma-activity levels of the natural radionuclides in the studied albite granite samples were measured (Figure5 and Table 2). The mean values were $66.75,87.6$ and $87.3 \mathrm{~Bq} / \mathrm{kg}$ for ${ }^{238} \mathrm{U}$, 46.2, 52.6 and $50.01 \mathrm{~Bq} / \mathrm{kg}$ for ${ }^{226} \mathrm{Ra}, 20.10,57.3$ and $31.58 \mathrm{~Bq} / \mathrm{kg}$ for ${ }^{232} \mathrm{Th}$ and $601.9,329.4$ and $833.91 \mathrm{~Bq} / \mathrm{kg}$ for ${ }^{40} \mathrm{~K}$ of the surface, adit and core samples, the median values $64.63,72.18 \mathrm{~Bq} / \mathrm{kg}$ for ${ }^{238} \mathrm{U}, 45,37.59 \mathrm{~Bq} / \mathrm{kg}$ for ${ }^{226} \mathrm{Ra}, 16.19,16.45 \mathrm{~Bq} / \mathrm{kg}$ for ${ }^{232} \mathrm{Th}$ and $650,300 \mathrm{~Bq} / \mathrm{kg}$ for ${ }^{40} \mathrm{~K}$ of the surface and adit samples (Table 6). Comparing the specific gamma-activity median values of ${ }^{238} \mathrm{U},{ }^{226} \mathrm{Ra},{ }^{232} \mathrm{Th}$ and ${ }^{40} \mathrm{~K}$ of the surface and adit samples(Table 6), it could be noticed that the adit samples have higher activity concentrations of ${ }^{238} \mathrm{U}$ and ${ }^{232} \mathrm{Th}$ than those found in the surface samples, whereas the highest ${ }^{40} \mathrm{~K}$ and ${ }^{226} \mathrm{Ra}$ concentration activities were associated with the core samples. This is attributed to the potash feldspar enriched with fresh and not altered $\mathrm{K}$. The mean values of ${ }^{238} \mathrm{U},{ }^{226} \mathrm{Ra},{ }^{232} \mathrm{Th}$ 
and ${ }^{40} \mathrm{~K}$ specific activities in the studied surface and adit samples were more or less equal to the mean values of the world granites that are 33 $\mathrm{Bq} / \mathrm{kg}$ for ${ }^{238} \mathrm{U}, 370 \mathrm{~Bq} / \mathrm{kg}$ for ${ }^{226} \mathrm{Ra}, 45 \mathrm{~Bq} / \mathrm{kg}$ for ${ }^{232} \mathrm{Th}$ and $412 \mathrm{~Bq} / \mathrm{kg}$ for ${ }^{40} \mathrm{~K}$ [31]. Due to the variation in the data, median values were also given for the comparisons.

Radiological hazards in environmental substances are estimated through various hazard parameters. Some available world averages and some limits were given in (Table 4 and Figure 10). The mean values of $\mathrm{Ra}_{\text {eq. }}$ of the studied albite granite were $153.79,159.8$ and $159.43 \mathrm{~Bq} / \mathrm{kg}$ for the surface, adit and core samples and median values were $125.855,93.68$ for the surface and adit samples respectively. Both mean and median values were less than $370 \mathrm{~Bq} / \mathrm{kg}$ which is the reference value recommended by the Organization of Economic Cooperation and Development [29].

$\mathrm{H}_{\text {in }}$ median and mean values were higher than $\mathrm{H}_{\mathrm{ex}}$ values due to the emission of radon gas [53]. $\mathrm{H}_{\text {in }}$ and $\mathrm{H}_{\mathrm{ex}}$ indices values of all samples were less than the unit $(<1)$, so the potential radiation health hazard was negligible for the samples (Figs. 7, 17and Table 3, 8).

While the gamma activity concentration index values of the surface, adit and core samples were $0.911,1.14$ and 1.12 in average respectively and the gamma dose contribution of the adit and core samples were exceeding in average the dose criterion $1 \mathrm{mSv} / \mathrm{y}$, the median values of the samples were less than the unit $(<1)$, (Figs. 7, 14 and Table 3, 11) [47, 51].

The absorbed dose rates in the air at $1 \mathrm{~m}$ level for the radionuclides can be calculated by equation 4 ; the contributions of the radionuclides are revealed in Figure 19a-c. According to the figure, for the adit and surface samples, the most important contribution was resulting from Ra-226 activity, but for the core samples the contribution was resulting from K-40. In the present study, the absorbed gamma dose mean values of the surface samples were $58.9 \mathrm{nGy} / \mathrm{h}$ and $73.6 \mathrm{nGy} / \mathrm{h}$ for the adit samples (Figure8 and Table 3). The adit samples tend to be slightly higher than $60 \mathrm{nGy} / \mathrm{h}$. However, the median values of absorbed gamma dose were $60.95 \mathrm{nGy} / \mathrm{h}$ for the surface samples and $46.43 \mathrm{nGy} / \mathrm{h}$ for the adit samples (Figure15 and Table 7). Although average adit samples seem to be higher than the world average because of the maximum values, it is clear that most of the radioactivity levels of the surface samples were not higher than the world average as revealed though comparisons.

The mean AEDR $\mathrm{out}_{\text {val }}$ values of the studied surface, adit and core samples were 0.07, 0.09,0.95 mSv/y respectively and median values were $0.075,0.06$ $\mathrm{mSv} / \mathrm{y}$ for the surface and adit samples. On the other hand, the mean values of $\mathrm{AEDR}_{\text {in }}$ for the surface, adit and core samples were $0.29,0.36$ and $0.37 \mathrm{mSv} / \mathrm{y}$ respectively and median values were 0.3 and $0.23 \mathrm{mSv} / \mathrm{y}$ for the surface and adit samples. Both the $\mathrm{AEDR}_{\text {out }}$ and the $\mathrm{AEDR}_{\text {in were }}$ less than the world mean value $(1 \mathrm{mSv} / \mathrm{y}),[42]$ (Figs. 8, 16 and Table 3, 10).

In the present study, the mean values of ELCR ${ }_{\text {out }} \mathrm{X}$ $10^{-4}$ for the surface, adit and core samples were $0.28 \times 10^{-4}, 0.35 \times 10^{-4}, 0.36 \times 10^{-4}$ and median values were $0.38 \times 10-4$ and $0.22 \times 10^{-4}$ for the surface and adit samples .Both mean and median values were found to be lower than the world ELCR $_{\text {out }}$ value $\left(2.90 \times 10^{-4}\right)$ (Figs. 9, 18 and Table $3,12)[31,55]$. Considering the present data, the average specific activity of ${ }^{238} \mathrm{U},{ }^{226} \mathrm{Ra},{ }^{232} \mathrm{Th}$ and ${ }^{40} \mathrm{~K}$ of the studied albite granite were $77.6,49.3$, 37.1 and $507.3 \mathrm{~Bq} / \mathrm{kg}$, which were lower values than those found in the other countries and worldwide ( Table 4 and Figure10). Nuweibi albite granite area [45], which is closely near to the current study area, its average specific activities of ${ }^{238} \mathrm{U},{ }^{232} \mathrm{Th}$ and ${ }^{40} \mathrm{~K}$ were higher than those found in Abu Dabbab albite granite.

Anomaly values of the risk parameters were observed at a very limited site along adit mining, nearby shear zones along and across outcrops. In general, the radiation hazard assessment showed that the radiological risk indices values in $\mathrm{Abu}$ Dabbab albite granite mining area were less than the permissible limits, especially for the surface samples. 
Table (4): World-wide average review of some granite literatures data of specific activity concentrations (Bq/kg) vs. the present study

\begin{tabular}{|c|c|c|c|c|c|c|}
\hline Location & Area of study & ${ }^{238} \mathbf{U}($ av. $)$ & ${ }^{226} \operatorname{Ra}(\mathrm{av})$. & ${ }^{232} \operatorname{Th}(\mathrm{av})$. & ${ }^{40} \mathbf{K}(\mathrm{av})$. & Reference \\
\hline $\begin{array}{l}\text { Worldwide } \\
\text { Average }\end{array}$ & ------- & 33 & 32 & 45 & 412 & UNSCEAR, 2008 \\
\hline Saudi Arabia & Ranyah Area & - & 45 & 39 & 1178 & $\begin{array}{l}\text { Zeghib et al., } \\
2016\end{array}$ \\
\hline $\begin{array}{l}\text { Worldwide } \\
\text { Average }\end{array}$ & -------- & - & 90 & 80 & 1200 & $\begin{array}{l}\text { UNSCEAR, } \\
1993\end{array}$ \\
\hline Yemen & $\begin{array}{l}\text { Na'wah Area Precambrian } \\
\text { granites }\end{array}$ & 156.8 & 69.2 & 83.6 & 2127.1 & Heikal et al., 2016 \\
\hline Egypt & Sharm El-Sheikh & 48.2 & 49.3 & 60.7 & 1278 & $\begin{array}{l}\text { Al-Sharkawy et } \\
\text { al., } 2012\end{array}$ \\
\hline Egypt & $\begin{array}{l}\text { CED, Nuweibi Area, Albite } \\
\text { granite }\end{array}$ & 138.3 & - & 121.5 & 1297.2 & $\begin{array}{l}\text { Gaafar, } \\
2014\end{array}$ \\
\hline Brazil & $\begin{array}{l}\text { Ceará State, white albite } \\
\text { granite }\end{array}$ & - & 160 & 61 & 856 & Anjos et al., 2011 \\
\hline \multirow{4}{*}{ Egypt } & \multirow{4}{*}{$\begin{array}{l}\text { CED, Abu Dabbab Mine, } \\
\text { Albite granite }\end{array}$} & 64.63 & 45 & 16.19 & 650 & $\begin{array}{lr}\text { Present } & \text { study, } \\
\text { median values } & \text { (Surface samples) }\end{array}$ \\
\hline & & 72.18 & 37.5 & 16.45 & 300 & $\begin{array}{l}\text { Present study, } \\
\text { median values } \\
\text { (Adit samples) }\end{array}$ \\
\hline & & 47.7 & 46.08 & 19.67 & 728.39 & $\begin{array}{l}\text { Present study, } \\
\text { median values } \\
\text { (Core sample) }\end{array}$ \\
\hline & & 94.68 & 54.173 & 43.47 & 939.42 & $\begin{array}{l}\text { Present } \\
\text { study(median) }\end{array}$ \\
\hline
\end{tabular}

Table (5): Summary statistics of Table 1 for the ground gamma-ray measurements for eU (ppm), eTh (ppm) and K\%

\begin{tabular}{|l|l|l|l|}
\hline Characterization & eU (ppm) & eTh (ppm) & K \% \\
\hline Count & 21 & 21 & 21 \\
\hline Average & 10.96 & 19.52 & 3.7 \\
\hline Median & 10 & 18.0 & 3.7 \\
\hline Standard deviation & 4.26 & 8.62 & 0.76 \\
\hline Minimum & 5.1 & 8.6 & 2.4 \\
\hline Maximum & 20.0 & 42.0 & 5.6 \\
\hline Range & 14.9 & 335.4 & 41.95 \\
\hline
\end{tabular}


Table (6): Summary statistics for of $C_{U}, C_{R a}, C_{T h}$ and $C_{K}$ specific activities of the studied albite granite from Abu Dabbab mining area

\begin{tabular}{|c|c|c|c|}
\hline \multicolumn{4}{|l|}{$\mathrm{C}_{\mathrm{u}}(\mathrm{Bq} / \mathrm{kg})$} \\
\hline Characterization & Surface & Adit & Core \\
\hline Count & 10 & 9 & 2 \\
\hline Average & 66.75 & 87.56 & 87.25 \\
\hline Standard deviation & 16.60 & 57.63 & 29.66 \\
\hline Median & 64.63 & 72.18 & - \\
\hline Minimum & 47.7 & 32.72 & 66.28 \\
\hline Maximum & 94.68 & 206.47 & 108.23 \\
\hline Range & 46.98 & 173.75 & 41.95 \\
\hline \multicolumn{4}{|l|}{$\mathrm{C}_{\mathrm{Ra}}(\mathrm{Bq} / \mathrm{kg})$} \\
\hline Statistics & Surface & Adit & Core \\
\hline Count & 10 & 9 & 2 \\
\hline Average & 46.172 & 52.5689 & 50.12 \\
\hline Standard deviation & 11.5429 & 30.1278 & 5.72 \\
\hline Median & 45 & 37.59 & - \\
\hline Minimum & 29.0 & 14.08 & $46.08(230 \mathrm{~m})$ \\
\hline Maximum & 61.64 & 113.16 & $54.17(200 \mathrm{~m})$ \\
\hline Range & 32.64 & 99.08 & 8.09 \\
\hline \multicolumn{4}{|l|}{$\mathrm{C}_{\mathrm{Th}}(\mathrm{Bq} / \mathrm{kg})$} \\
\hline Statistics & Surface & Adit & Core \\
\hline Count & 10 & 9 & 2 \\
\hline Average & 20.05 & 57.27 & 31.57 \\
\hline Standard deviation & 11.01 & 69.19 & 16.82 \\
\hline Median & 16.19 & 16.45 & - \\
\hline Minimum & 9.47 & 8.59 & $19.67(230 \mathrm{~m})$ \\
\hline Maximum & 45.1 & 198.07 & $43.47(200 \mathrm{~m})$ \\
\hline Range & 35.63 & 189.48 & 23.8 \\
\hline \multicolumn{4}{|l|}{$\mathrm{C}_{\mathrm{K}}(\mathrm{Bq} / \mathrm{kg})$} \\
\hline & Surface & Adit & \begin{tabular}{|l|} 
Core \\
\end{tabular} \\
\hline Count & 10 & 9 & 2 \\
\hline Average & 601.98 & 329.38 & 833.90 \\
\hline Standard deviation & 273.42 & 239.16 & 149.22 \\
\hline Median & 650 & 300 & - \\
\hline Minimum & 74.25 & 66.81 & $728.39(230 \mathrm{~m})$ \\
\hline Maximum & 1051.62 & 659.35 & $939.42(200 \mathrm{~m})$ \\
\hline Range & 977.37 & 592.54 & 211.03 \\
\hline
\end{tabular}

Table (7): Summary statistics for $\mathbf{R a}_{\mathrm{e} 0}$

\begin{tabular}{|l|l|l|l|l|l|l|l|}
\hline $\begin{array}{l}\text { Sample } \\
\text { type }\end{array}$ & Count & Average & $\begin{array}{l}\text { Standard } \\
\text { deviation }\end{array}$ & Median & Minimum & Maximum & Range \\
\hline Surface & 10 & 121.20 & 28.97 & 125.85 & 59.38 & 153.79 & 94.41 \\
\hline Adit & 10 & 159.22 & 123.69 & 93.68 & 55.8 & 427.89 & 372.09 \\
\hline Core & 2 & 159.49 & 6.85 & - & $154.65(230 \mathrm{~m})$ & $164.34(200 \mathrm{~m})$ & 9.69 \\
\hline
\end{tabular}


Table (8): Summary statistics for calculated $H_{\mathrm{ex}}$ and $\mathbf{H}_{\text {in }}$ values

\begin{tabular}{|l|l|l|l|l|l|l|l|}
\hline Characterization & Count & Average & $\begin{array}{l}\text { Standard } \\
\text { deviation }\end{array}$ & Median & Minimum & Maximum & Range \\
\hline Surface-out & 10 & 0.32 & 0.07 & 0.34 & 0.16 & 0.42 & 0.26 \\
\hline Surface-in & 10 & 0.45 & 0.1 & 0.47 & 0.24 & 0.58 & 0.34 \\
\hline Adit-out & 9 & 0.43 & 0.35 & 0.25 & 0.15 & 1.16 & 1.01 \\
\hline Adit-in & 9 & 0.57 & 0.43 & 0.38 & 0.2 & 1.46 & 1.26 \\
\hline
\end{tabular}

Table (9): Summary statistics for calculated absorbed gamma dose rate

\begin{tabular}{|l|l|l|l|l|l|l|l|}
\hline $\begin{array}{l}\text { Sample } \\
\text { type }\end{array}$ & Count & Average & $\begin{array}{l}\text { Standard } \\
\text { deviation }\end{array}$ & Median & Minimum & Maximum & Range \\
\hline Surface & 10 & 58.88 & 14.10 & 60.95 & 27.2 & 73.79 & 46.59 \\
\hline Adit & 9 & 73.59 & 58.29 & 46.43 & 25.94 & 192.33 & 166.39 \\
\hline Core & 2 & 77.54 & 1.58 & - & $\begin{array}{l}76.42 \\
(230 \mathrm{~m})\end{array}$ & $\begin{array}{l}78.66 \\
(200 \mathrm{~m})\end{array}$ & 2.24 \\
\hline
\end{tabular}

Table (10): Summary Statistics for AEDR indoor and AEDR outdoor values

\begin{tabular}{|l|l|l|l|l|l|l|l|}
\hline $\begin{array}{l}\text { Characterizatio } \\
\text { n }\end{array}$ & Count & Average & $\begin{array}{l}\text { Standard } \\
\text { deviation }\end{array}$ & Median & Minimum & Maximum & Range \\
\hline Surface-out & 10 & 0.07 & 0.018 & 0.075 & 0.03 & 0.09 & 0.06 \\
\hline Surface-in & 10 & 0.28 & 0.069 & 0.3 & 0.13 & 0.36 & 0.23 \\
\hline Adit-out & 9 & 0.09 & 0.071 & 0.06 & 0.03 & 0.24 & 0.21 \\
\hline Adit-in & 9 & 0.36 & 0.285 & 0.23 & 0.13 & 0.94 & 0.81 \\
\hline Core-out & 2 & 0.09 & 0.007 & - & 0.09 & 0.1 & 0.01 \\
\hline Core-in & 2 & 0.38 & 0.014 & - & 0.37 & 0.39 & 0.02 \\
\hline
\end{tabular}

Table (11): Summary statistics for I $\gamma$

\begin{tabular}{|l|l|l|l|l|l|l|l|}
\hline $\begin{array}{l}\text { Sample } \\
\text { type }\end{array}$ & Count & Average & $\begin{array}{l}\text { Standard } \\
\text { deviation }\end{array}$ & Median & Minimum & Maximum & Range \\
\hline Surface & 10 & 0.91 & 0.21 & 0.94 & 0.42 & 1.14 & 0.72 \\
\hline Adit & 9 & 1.14 & 0.91 & 0.72 & 0.39 & 3.01 & 2.62 \\
\hline Core & 2 & 1.205 & 0.03 & - & $1.18(230 \mathrm{~m})$ & $1.23(200 \mathrm{~m})$ & 0.05 \\
\hline
\end{tabular}

Table (12): Summary statistics for ELCR $_{\text {out }}$ value

\begin{tabular}{|l|l|l|l|l|l|l|l|}
\hline $\begin{array}{l}\text { Sample } \\
\text { type }\end{array}$ & Count & Average & $\begin{array}{l}\text { Standard } \\
\text { deviation }\end{array}$ & Median & Minimum & Maximum & Range \\
\hline Surface & 10 & 0,27 & 0,06 & 0,38 & 0,13 & 0,35 & 0,22 \\
\hline Adit & 9 & 0,34 & 0,27 & 0,22 & 0,12 & 0,91 & 0,79 \\
\hline Core & 2 & 0,365 & 0.00 & - & $0,36(230 \mathrm{~m})$ & $0,37(200 \mathrm{~m})$ & 0,01 \\
\hline
\end{tabular}

Table (13): T-test results for $H_{\mathrm{ex}}, H_{\text {in }}$ indices of the surface and adit samples

\begin{tabular}{|l|l|l|}
\hline & Surface samples & Adit samples \\
\hline Null hypothesis & Mean $\mathrm{H}_{\mathrm{ex}}=$ Mean $\mathrm{H}_{\mathrm{in}}$ \\
\hline $\mathbf{9 5 , 0 \%}$ Confidence intervals & $\mathrm{H}_{\mathrm{ex}}[0.27 ; 0.38]$ & $\mathrm{H}_{\mathrm{ex}}[0.15 ; 0.70]$ \\
& $\mathrm{H}_{\mathrm{in}}[0.37 ; 0.52]$ & $\mathrm{H}_{\mathrm{in}}[0.23 ; 0.90]$ \\
\hline P-value & 0.00713749 & 0.046112 \\
\hline
\end{tabular}


Table (14): Mann-Whitney (Wilcoxon) W-test results for $H_{\mathrm{ex}}, \mathbf{H}_{\mathrm{in}}$ indices of the surface and adit samples

\begin{tabular}{|l|l|l|}
\hline Null hypothesis : median $\mathbf{H}_{\mathrm{ex}}=$ median $\mathbf{H}_{\mathrm{in}}$ \\
\hline Characterization & Surface Samples & Adit Samples \\
\hline Median of $\mathbf{H}_{\mathrm{ex}}$ & 0.34 & 1.02 \\
Median of $\mathbf{H}_{\mathrm{ex}}$ & 0.47 & 0.38 \\
\hline Average rank of $\mathbf{H}_{\mathrm{ex}}$ & 7.05 & 9.94 \\
Average rank of $\mathbf{H}_{\mathrm{in}}$ & 13.95 & 11.05 \\
\hline P-value & 0.01 & 0.23 \\
\hline
\end{tabular}

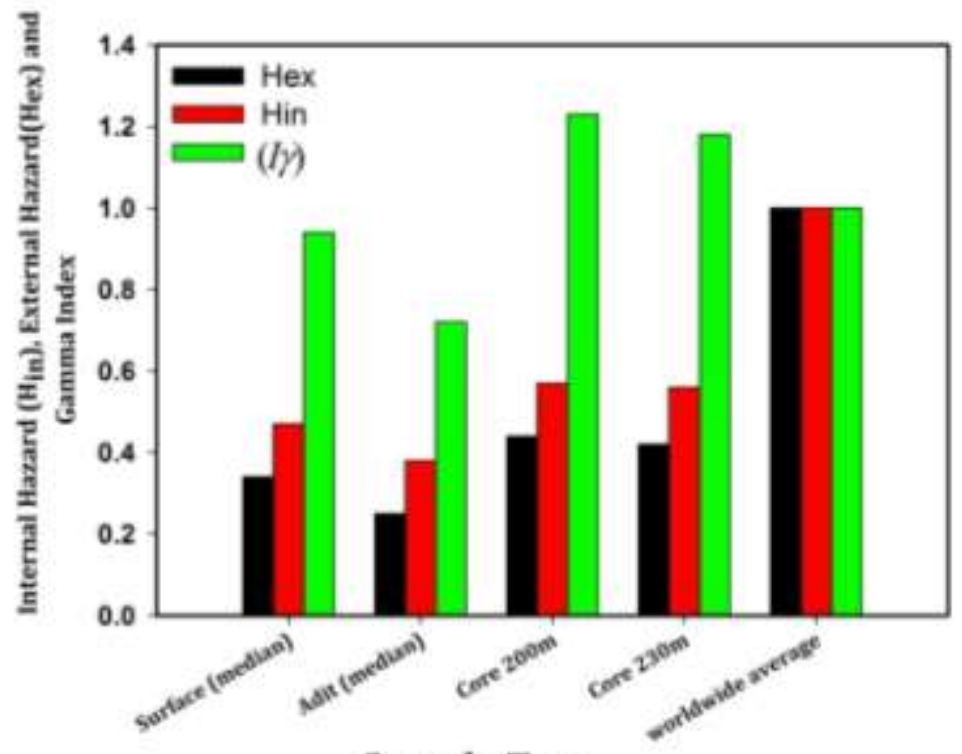

Sample Type

Figure(7): Median values of $\mathrm{I} \gamma, \mathrm{H}_{\mathrm{ex}}$, and $\mathrm{H}_{\mathrm{in}}$ of Abu Dabbab albite granite compared to worldwide average [50]

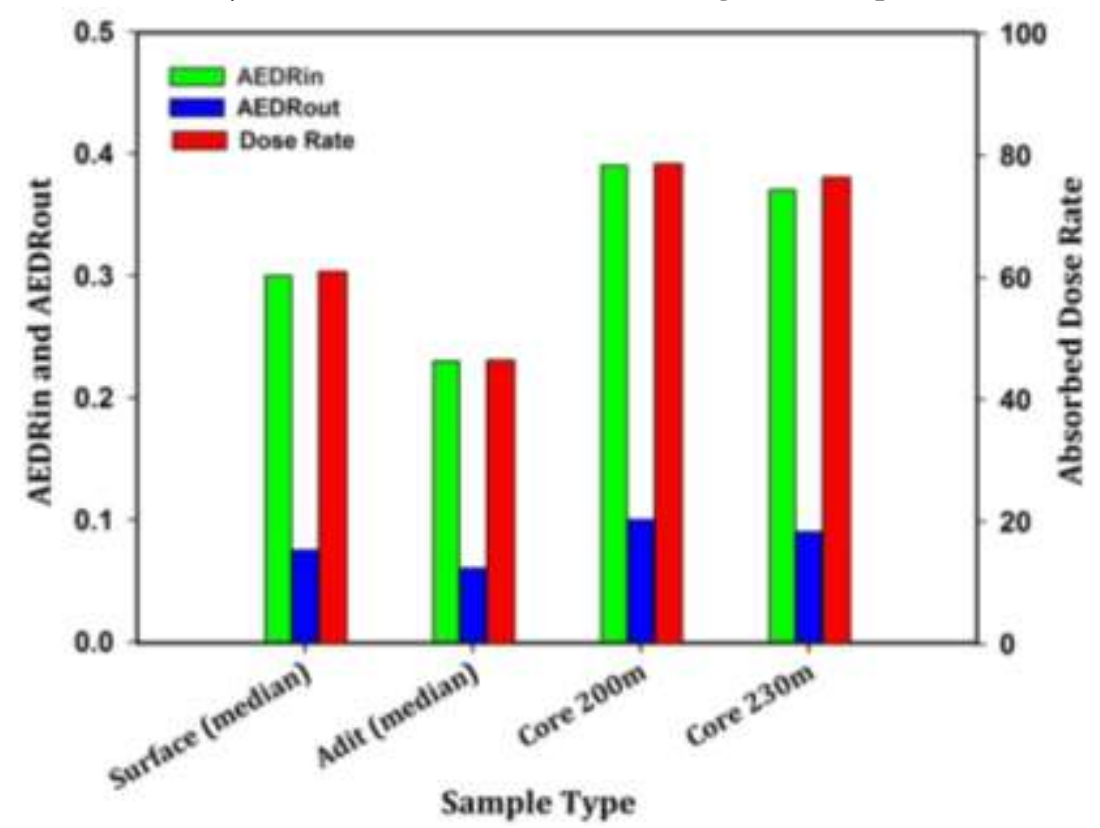

Figure(8): Median values of Absorbed Dose Rate and AEDR of Abu Dabbab albite granite compared to the worldwide dose rate $\left(58 \mathrm{ngh}^{-1}\right)$ and permissible level of $\operatorname{AEDR}(1 \mathrm{mSv} / \mathrm{y})$ 


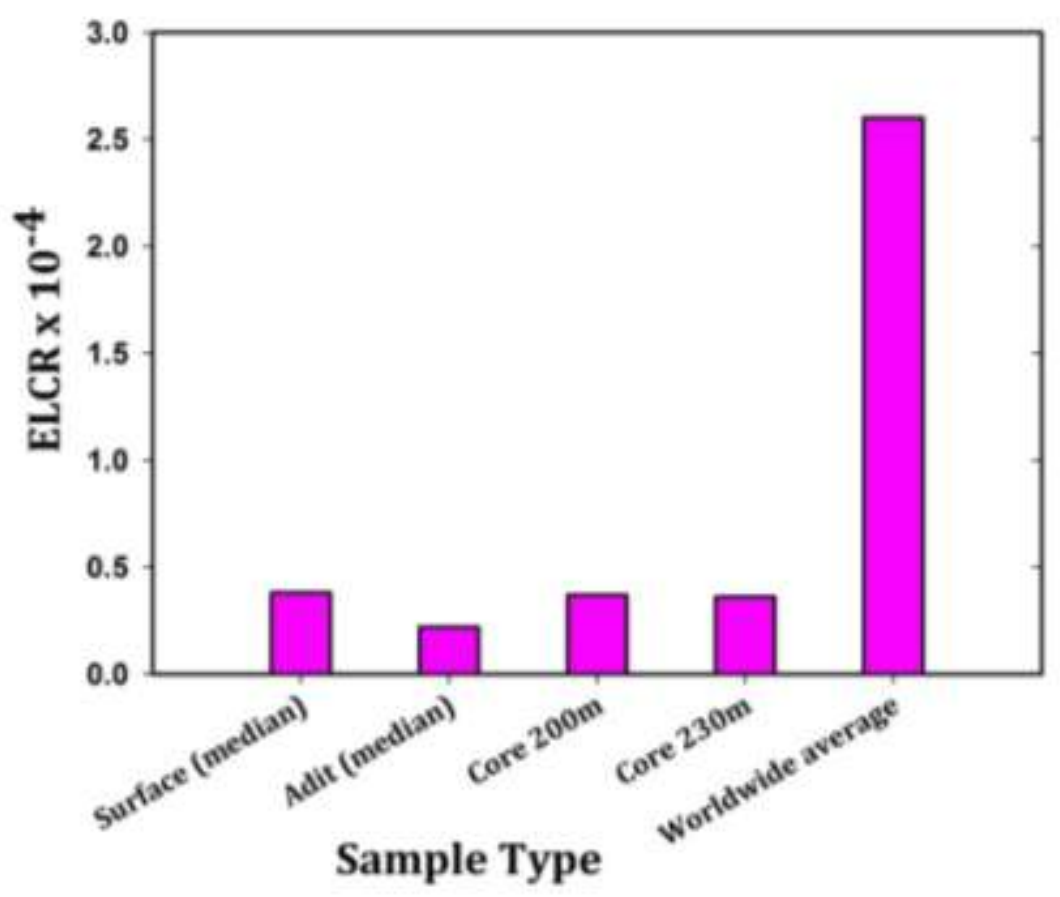

Figure(9): Median values of ELCRout for the albite granites of Abu Dabbab area, compared to the worldwide average [55]

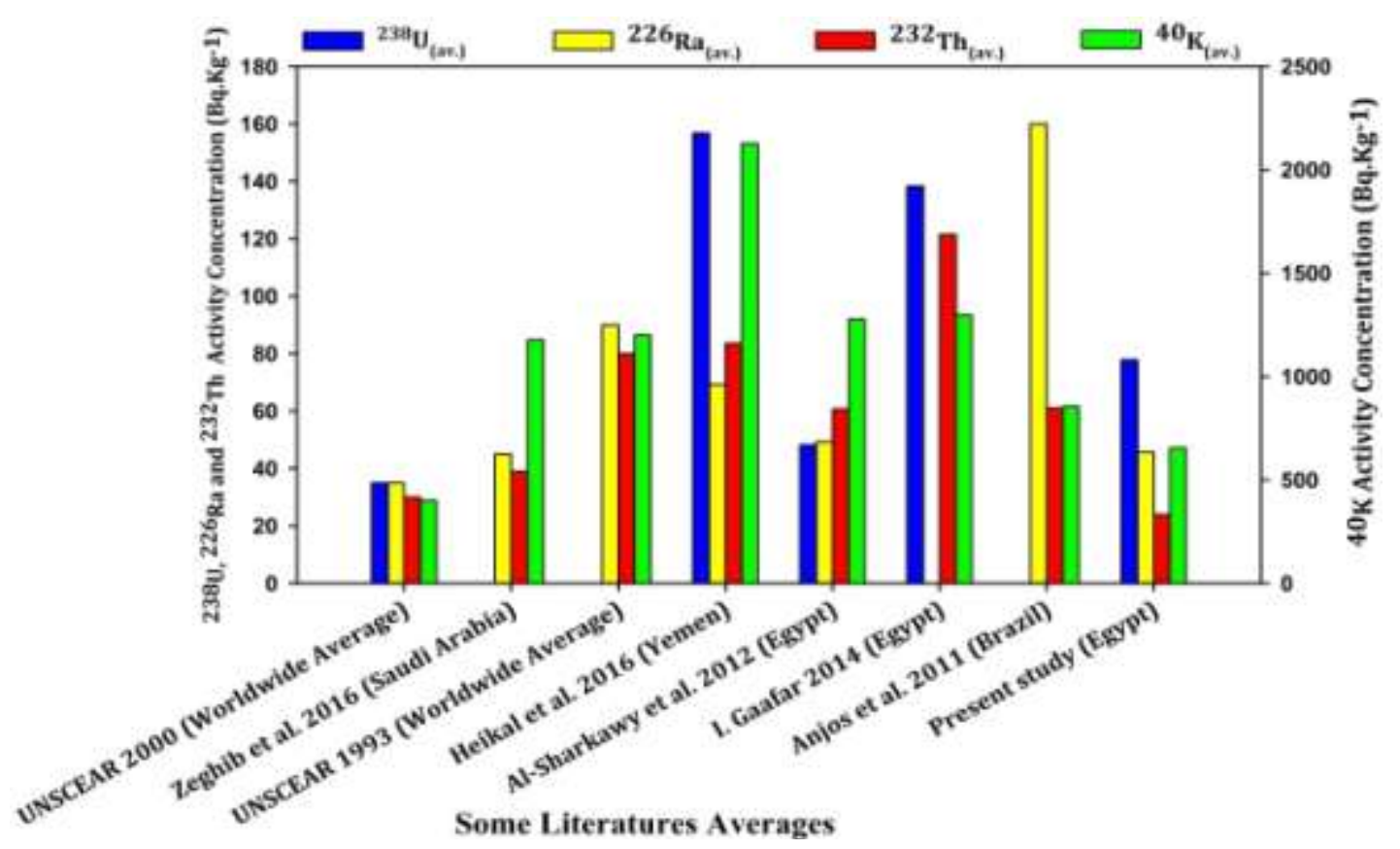

Figure(10): A comparison of the ${ }^{238} \mathrm{U},{ }^{232} \mathrm{Th},{ }^{226} \mathrm{Ra}$ and ${ }^{40} \mathrm{~K}$ average activity concentrations $\left(\mathrm{Bq} \cdot \mathrm{kg}^{-1}\right) \mathrm{compared} \mathrm{with}^{-1}$ worldwide average and some literatures 

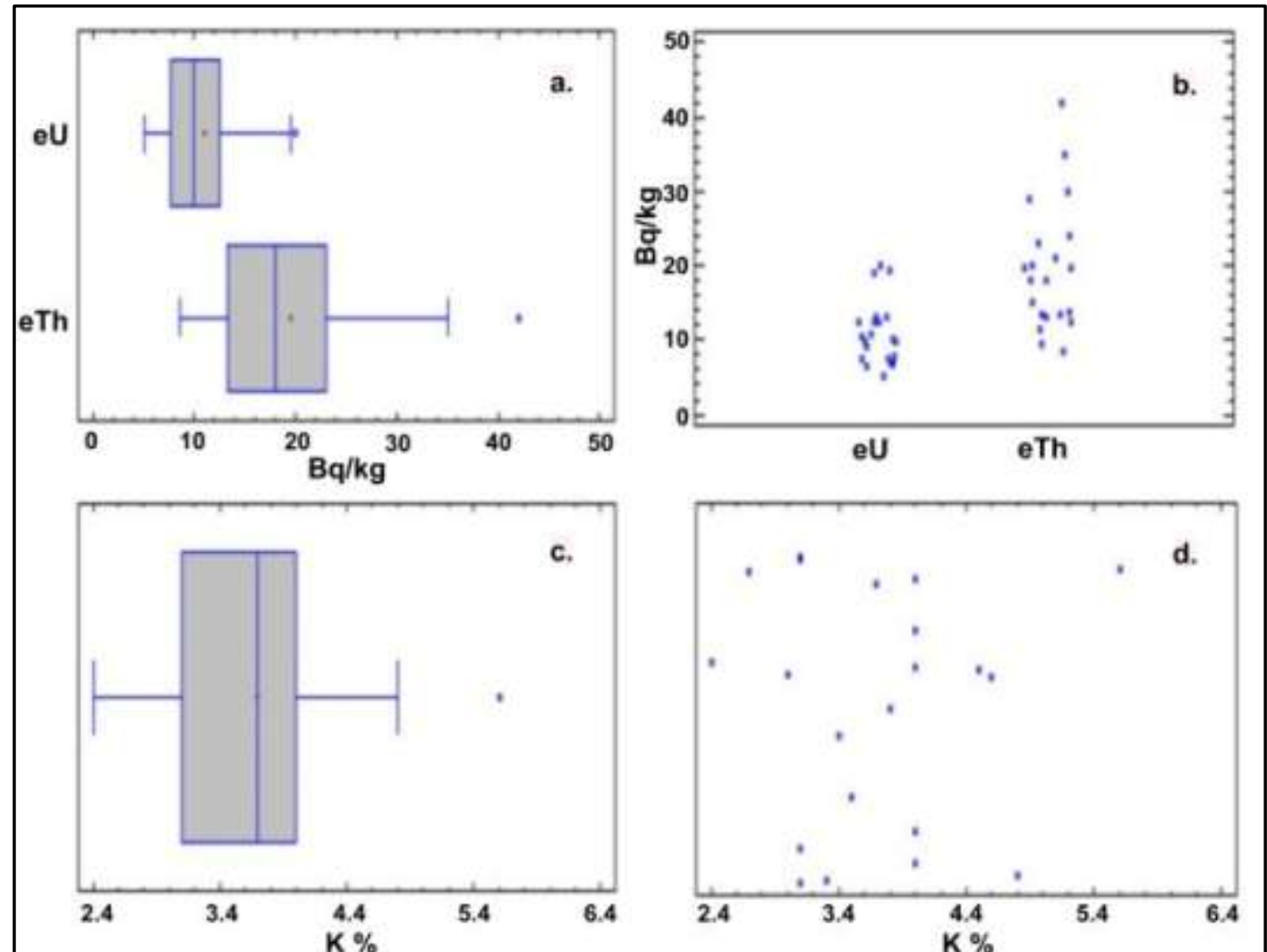

Figure (11a-d): a. Statistical analysis of Box and Wisker plot of ground gamma-ray spectrometric measurements for eU, eTh (ppm), Outliers were P5 for eU (ppm) measurements and P1 was for eTh (ppm) measurements, b. Scatter plot of ground gamma-ray spectrometric measurements for eU, eTh (ppm), c. Box and whisker plot of K\%, P20 was the outlier, d. Scatter plot of ground gamma-ray spectrometric measurements for K\%

\section{Conclusions}

From the radiological risk point of view, the study was carried out on surface, adit and core samples of the Abu Dabbab albite granite mining area from the central Nubian Shield of Egypt to determine the radioactivity dose distributions and their potential health effects to estimate human exposure.

Faults and shear zones play an important role as they act as pathways or channels for the ascending hydrothermal solutions. Due to the mobilization of radionuclides by the help of the hydrothermal solutions, vein-type outcrops were performed and gamma-radioactivity levels along the fractures usually were higher than the background level of the massive albite granite.

Stress-correlated deformations at the shear zones were probably responsible for the higher level of outdoor gamma dose level. The zones should be detected in terms of radon because they have the potential for creating anomalously high amounts of radon.

After statistical analyses and data mining, it is clear that local heterogeneities of the radionuclide distribution were obvious. Alteration rate differences, magma processes, remineralization after mobilization of the radionuclides represent some reasons for this distribution. Due to the heterogeneities, the median values were more advantageous than the mean values. Almost the median values of the studied area were lower than the permissible level of unity (1.0) for AEDR (indoor and outdoor), $\mathrm{H}_{\text {in }}$ and $\mathrm{H}_{\mathrm{ex}}$. Accordingly, the $\mathrm{Abu}$ Dabbab albite granites mining area is safe and there is no radiological risk in terms of human health. 


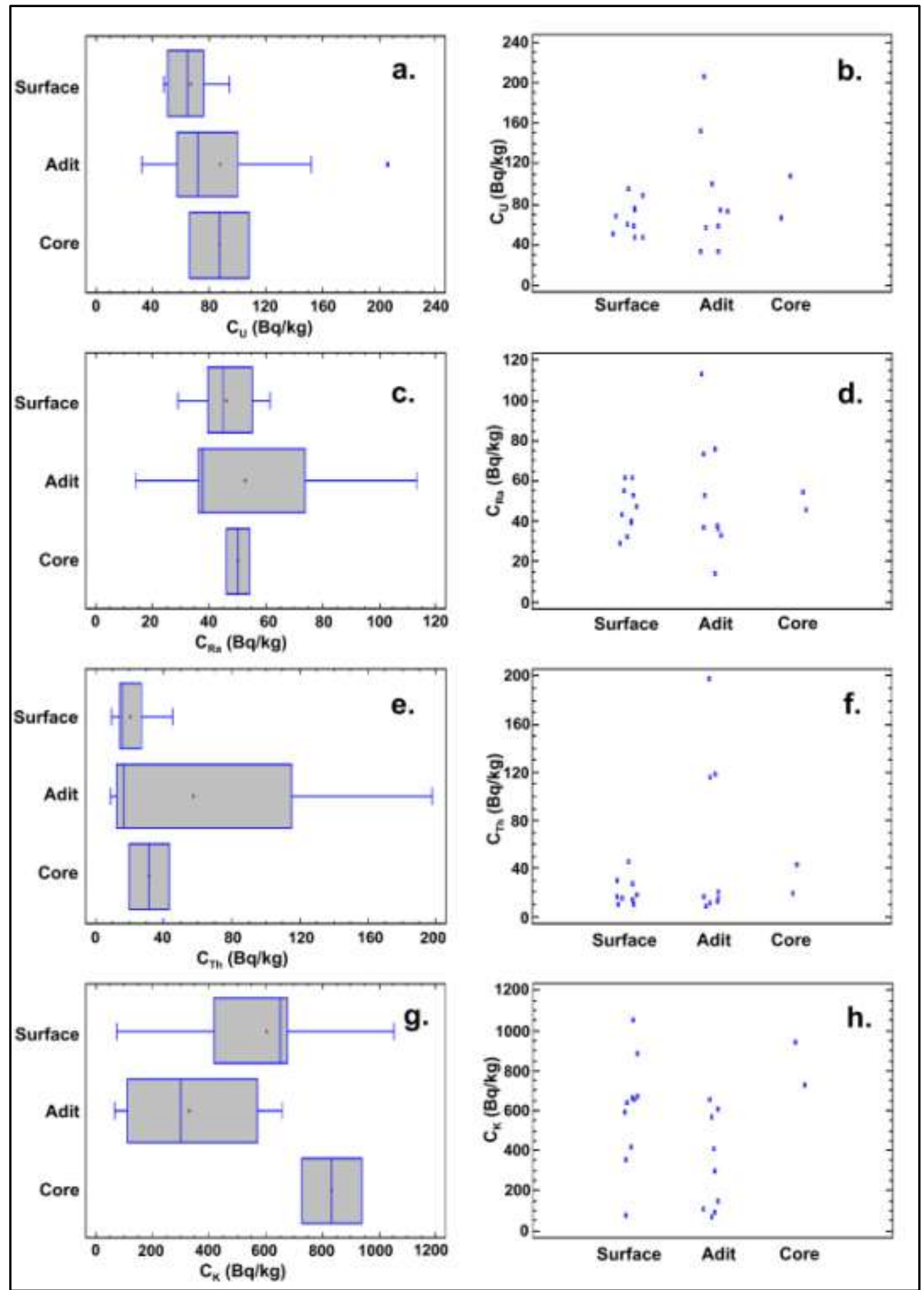

Figure(12a-h) : Box and Whisker plots of the specific activity concentrations (Table 2) of surface, core and adit samples: a. $C_{U}$, sample 16 in adit samples was outlier, c. $C_{R a}$, e. $C_{T h}, g . C_{K}$ in $(B q / k g)$. Scatter plots of the radioactivity levels of surface, core and adit samples: b. $C_{U}$, d. $C_{R a}$, f. $C_{T h}, h . C_{K}$ in $(B q / k g)$ 
M.TH.S. HEIKAL et al.

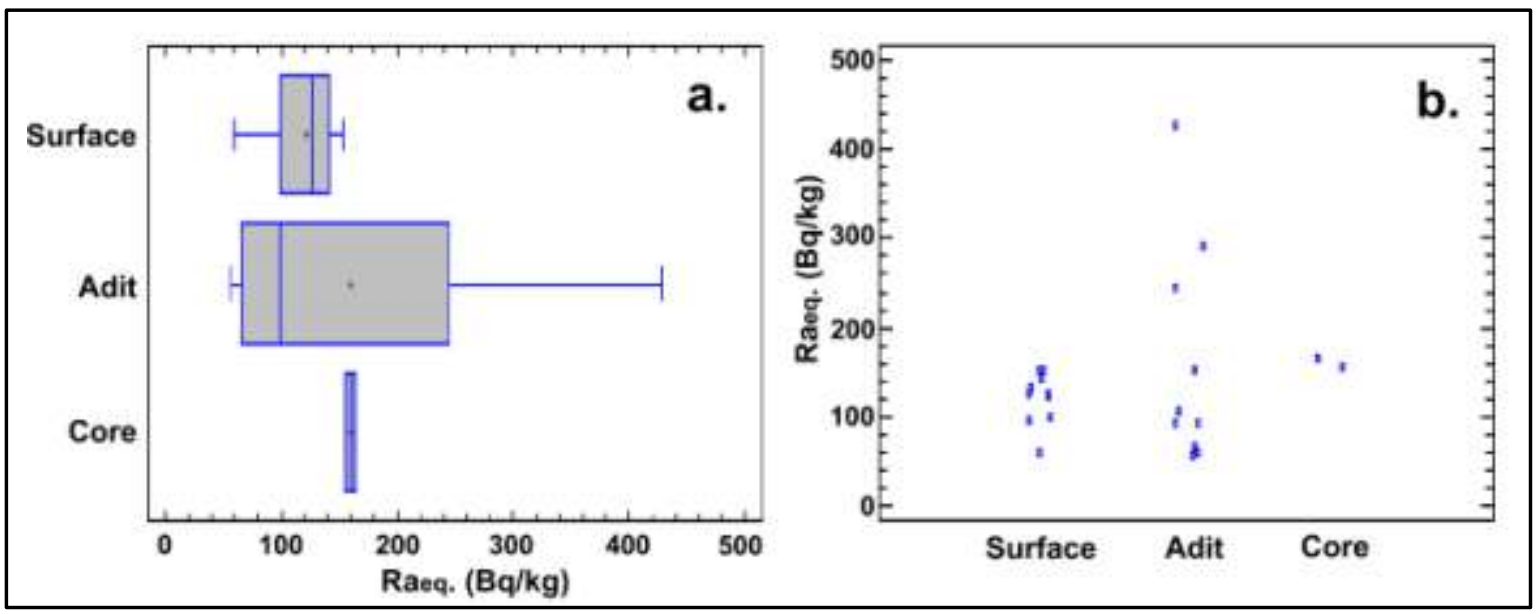

Figure(13a-b): a. Box and Whisker plot of $R a_{\text {eq. }}$ b. Scatter plot of $R a_{\text {eq }}$.

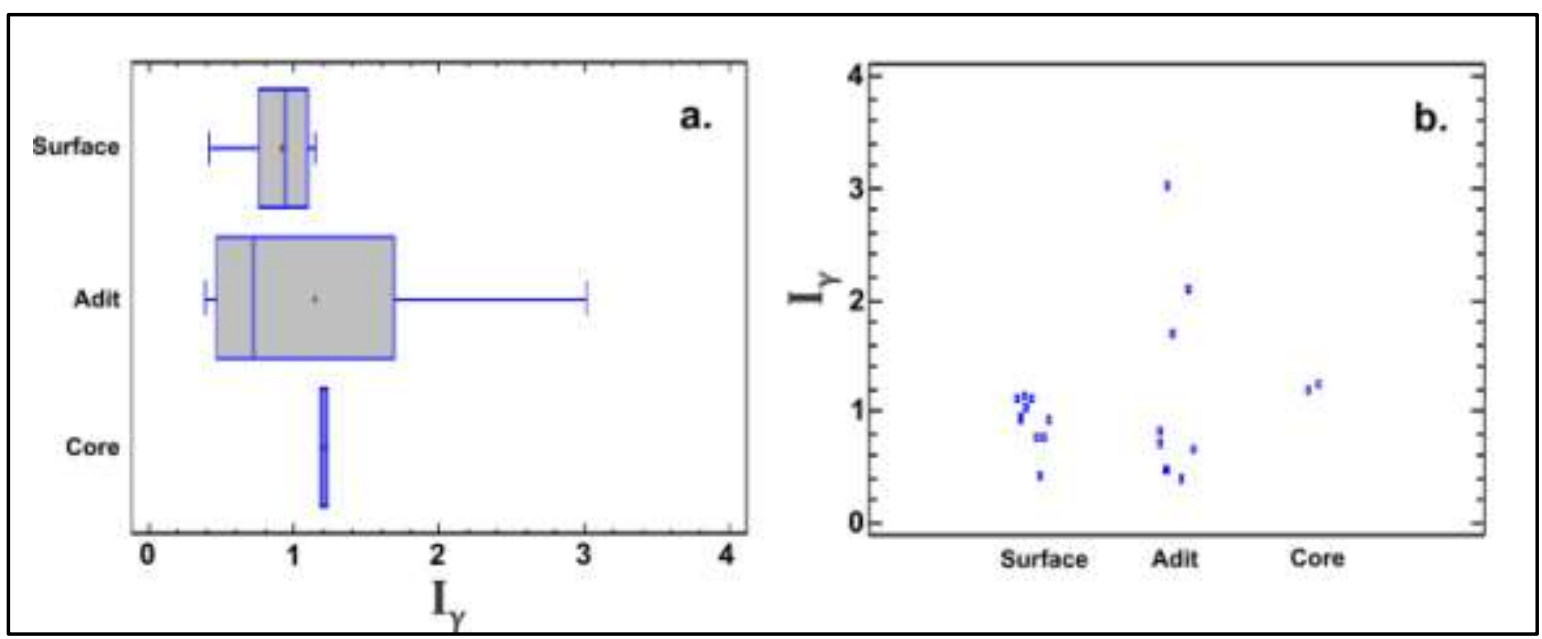

Figure(14a-b): a. Box and Whisker plot of $H_{e x}$ and $H_{i n}$, b. Scatter plot of calculated $H_{e x}$ and $H_{i n}$. Surface- $H_{e x}: S-H_{e x}$, Adit- $H_{\mathrm{ex}}: A-H_{\mathrm{ex}}$ and Core- $\mathrm{H}_{\mathrm{ex}}: C-\mathrm{H}_{\mathrm{ex}}$ are the abbreviations of $\mathrm{H}_{\mathrm{ex}}$ values of the samples. Surface- $\mathrm{H}_{\mathrm{in}}: \mathrm{S}-\mathrm{H}_{\mathrm{in}}$, Adit- $\mathrm{H}_{\mathrm{in}}$ : $A-H_{\text {in }}$, and Core- $H_{\text {in }}: C-H_{\text {in }}$ are the abbreviations of $H_{\text {in }}$ values of samples

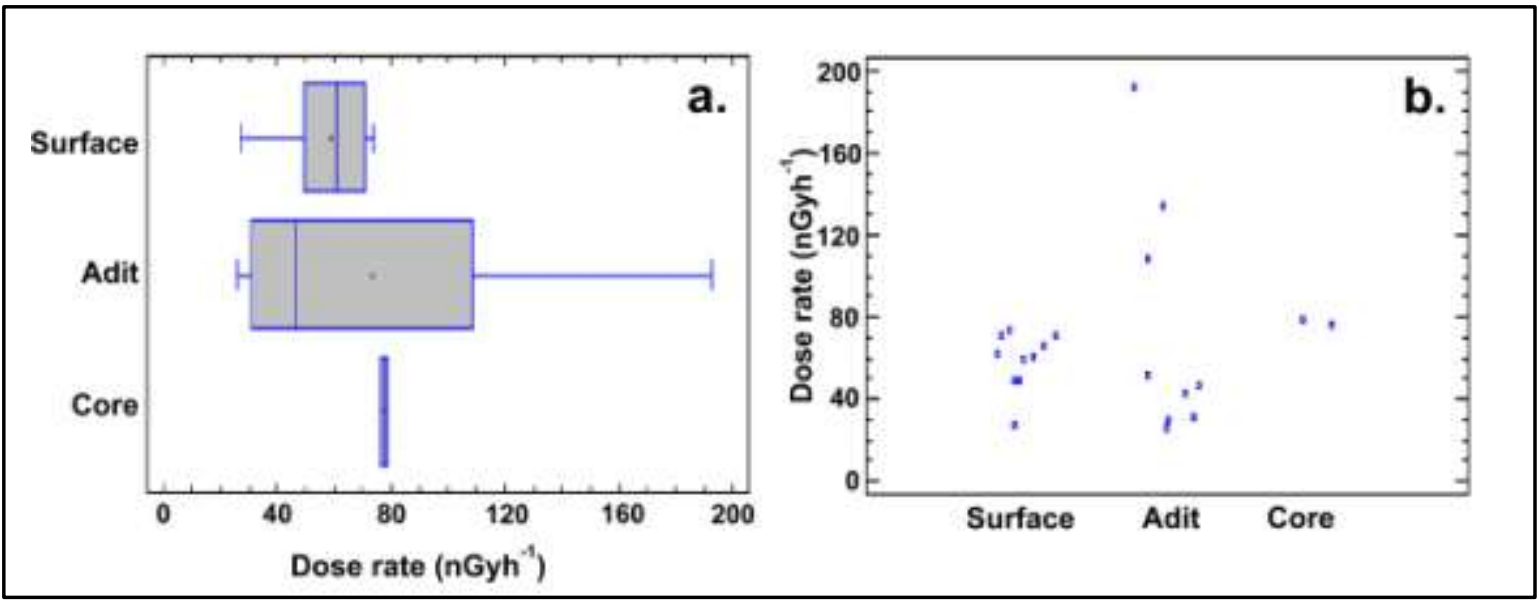

Figure(15a-b): a. Box and Whisker plots of absorbed gamma dose rate, b. Scatter plots of absorbed gamma dose rate 


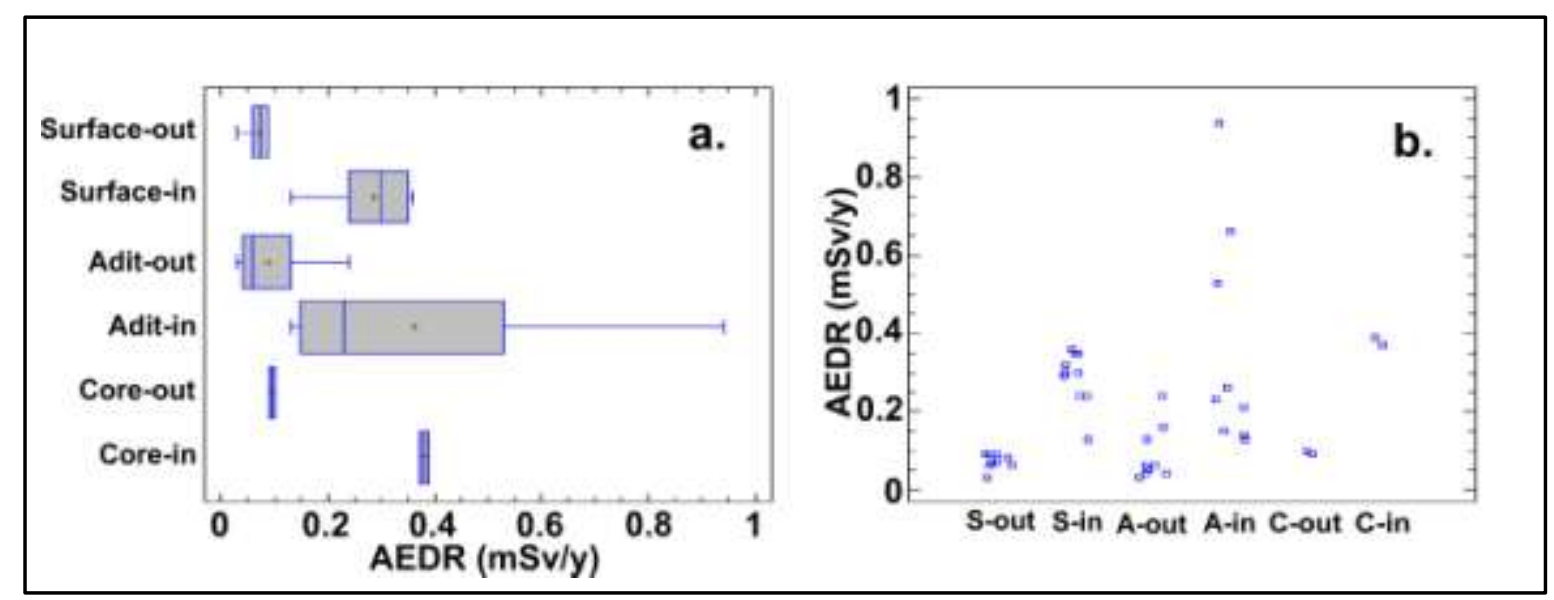

Figure(16a-b): a. Box and Whisker plots of AEDR outdoor and indoor, b. Scatter plots of AEDR outdoor and indoor values. Surface-out: S-out, Adit-out: A-out and Core-out: C-out are the abbreviations of AEDR outdoor values of the samples. Surface-in: S-in, Adit-in: A-in, and Core-in: C-in are abbreviations of AEDR indoor values of samples

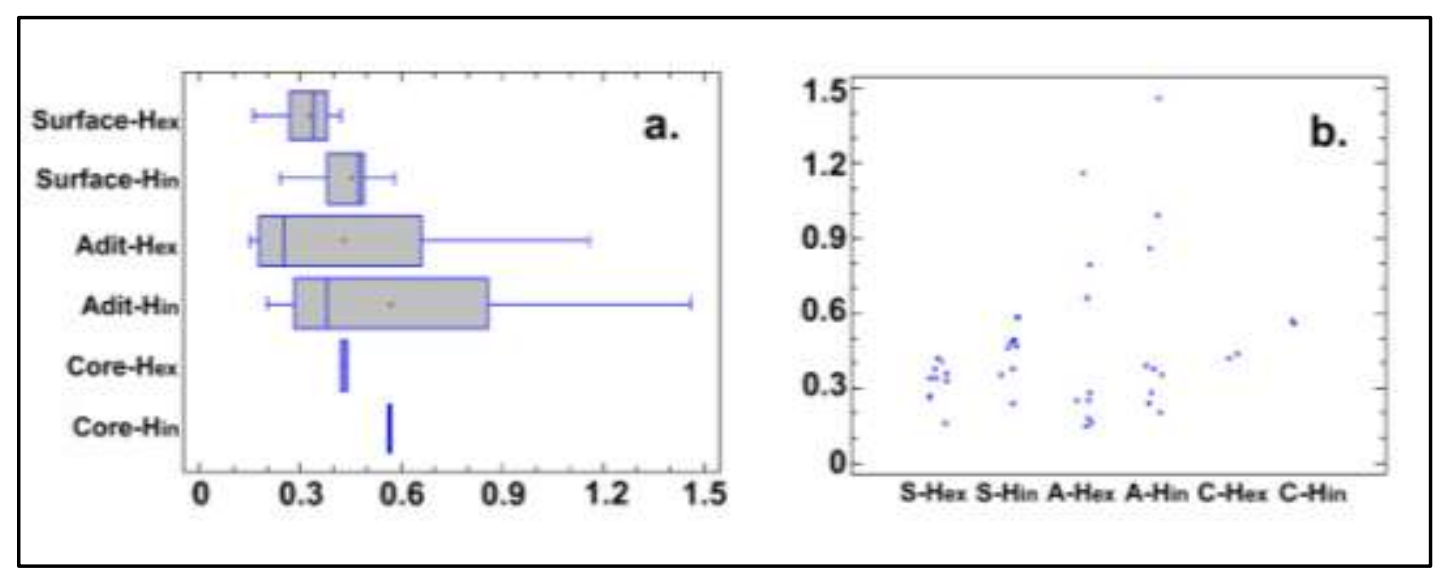

Figure(17a-b): a. Box and Whisker plot of $H_{e x}$ and $H_{i n}$, b. Scatter plot of calculated $H_{e x}$ and $H_{i n}$. Surface- $H_{e x}, S-H_{e x}$, Adit- $H_{e x}, A-H_{e x}$ and Core- $H_{e x}, C-H_{e x}$ are abbreviation of $H_{e x}$ values of the samples. Surface- $H_{i n}, S-H_{i n}, A d i t-H_{i n}, A-$ $H_{i n}$, and Core- $H_{i n}, C-H_{i n}$ are abbreviation of $H_{i n}$ values of samples

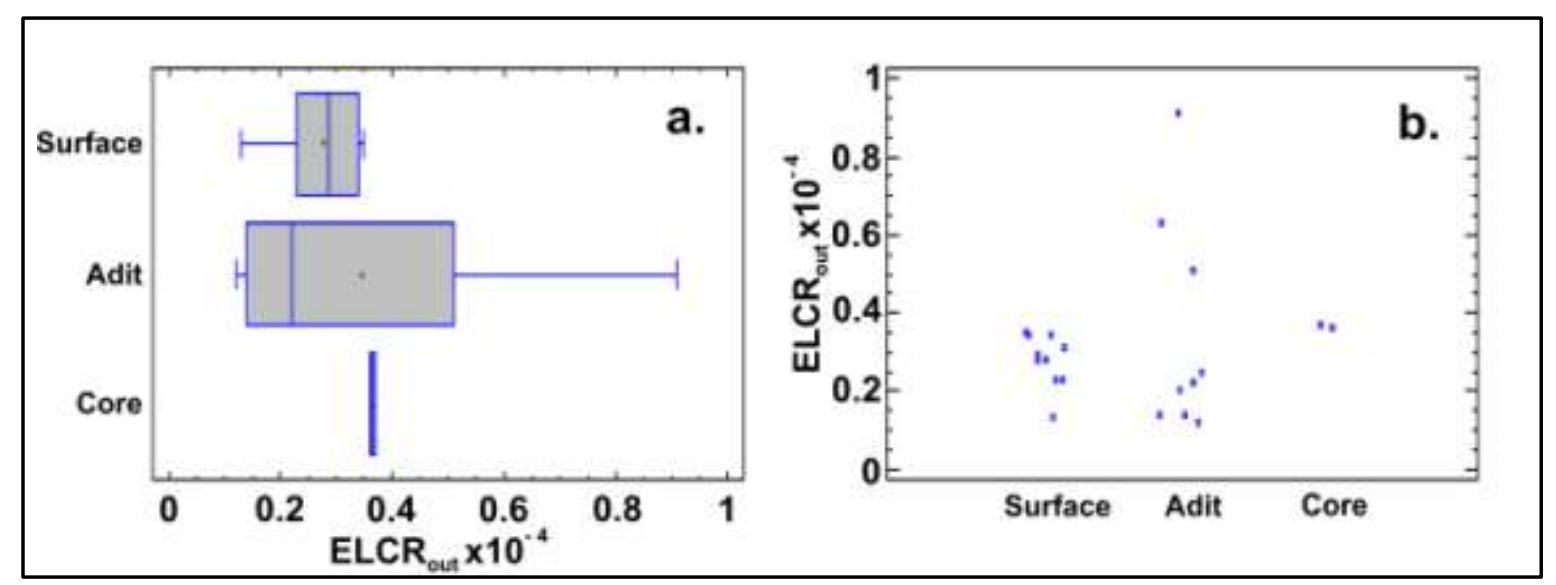

Figure(18a-b): a. Box and Whisker plot of $\operatorname{ELCR}_{\text {out }}$ b. Scatter plot of ELCR out 


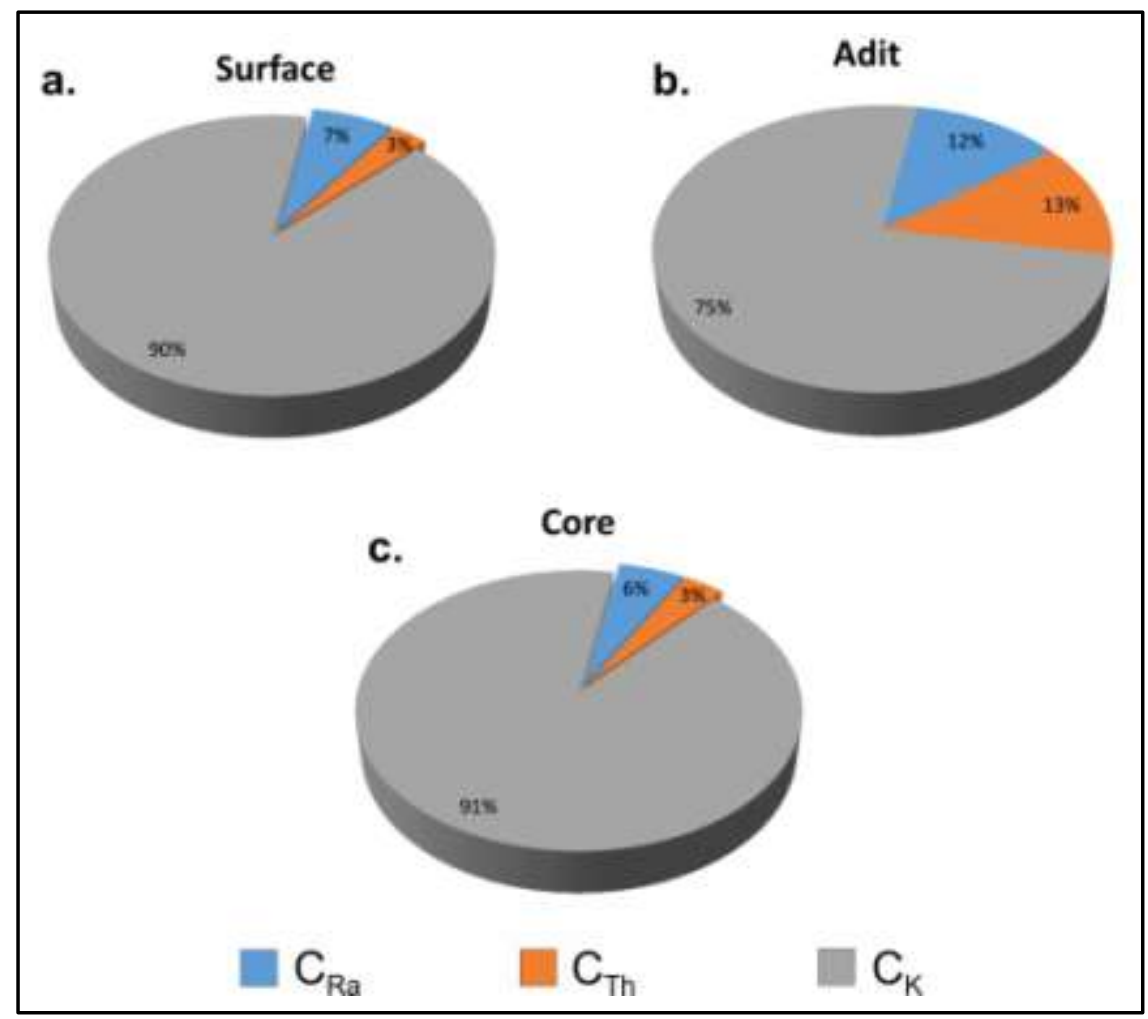

Figure(19a-c): Absorbed gamma dose contributors. $\mathrm{C}_{\mathrm{Ra}}$ : Contribution of radium gamma activity, $\mathrm{C}_{\mathrm{Th}}$ : Contribution of thorium gamma activity and $\mathrm{C}_{\mathrm{K}}$ : Contribution of potassium gamma activity. a. Surface samples, $b$. Adit samples, $c$. Core samples

\section{Acknowledgements}

The authors wish to thank and appreciate the technicians at the Egyptian Nuclear and Radiological Regulatory Authority, for their help in radioelements analysis. Special thanks should be extended to Prof. Farrage M. Khaleal, the Nuclear Materials Authority (NMA), Egypt for his help in the field spectrometric measurements.

\section{References}

1- IAEA, "Management of radioactive waste from the mining and milling of ores", IAEA Safety Standard Series No WS-G, 1.2, 27 (2002).

2- IAEA, "Occupational Radiation Protection in the Mining and Processing of Raw Materials", International Labour Office, IAEA Safety Standards Series No. RS-G-1.6, IAEA, Vienna (2004).

3- IAEA, "Assessing the Need for Radiation Protection Measures in Work Involving Minerals and Raw Materials", Safety Reports Series No. 49, IAEA, Vienna (2006).
4- Nwankwo, C. U, Ogundare, F. O, Folley, D. E., "Radioactivity concentration variation with depth and assessment of workers' doses in selected mining sites", Journal of Radiation Research and Applied Sciences $8,1,216-220$ (2015).

5- UNSCEAR, "United Nations Scientific Committee on the Effects of Atomic Radiation, Sources, Effects and Risks of Ionizing Radiation", Report to General Assembly, with Scientific Annex B: Exposure from Natural Sources of Radiation, United Nations, New York (2000).

6- Ademola, A K., Bello, A. K., Adejumobi, A C., "Determination of natural radioactivity and hazard in soil samples in and around gold mining area in Itagunmodi, south-western, Nigeria", Journal of radiation research and appliedsciences7,3,249-255 (2004).

7- Koranda, J. J., Robison W. L., "Accumulation of radionuclides by plants as a monitor system", Environmental health perspectives, 27,165-79 (1978). 
8- Froidevaux, P., Bochud, F., Haldimann, M., "Retention half times in the skeleton of plutonium and 90Sr from above-ground nuclear tests: a retrospective study of the Swiss population", Chemosphere, 80, 5, 51952480,5,519-524.

DOI: 10.1016/j.chemosphere.2010.04.049 (2010).

9- Ziajahromi, S., Khanizadeh M., Nejadkoorki, F., "Using the RESRAD code to assess human exposure risk to ${ }^{226} \mathrm{Ra},{ }^{232} \mathrm{Th}$ and ${ }^{40} \mathrm{~K}$ in soil", Human Ecol. Risk Assess. DOI: 10.1080/10807039.2014.909194 (2014).

10- USEPA, (United States Environmental Protection Agency) Title 40 Code of Federal Regulations, Section 70. 2. [(Accessed on 20 October 2014)] (2009a).

11- Cuney, M., "The extreme diversity of uranium deposits", Miner. Deposita, 44, 3-9 (2009).

12- Carvalho, F.P., "Environmental radioactive impact associated to uranium production", Am J Environ Sci., 7, 6, 547-553 (2011).

13- IAEA, "Radiation Protection and NORM Residue Management in the Production of Rare Earths from Thorium Containing Minerals", Safety Reports Series No. 68, Vienna (2011).

14- Basic Safety Standards, "Council Directive 2013/59/Euratom of 5 December 2013 laying down basic safety standards for protection against the dangers arising from exposure to ionizing radiation, and repealing Directives 89/618/euratom,90/641/Euratom,

96/29/Euratom, 97/43/Euratom and 2003/122/Euratom", Official Journal of the European Union 57, L13 (2013).

15- EURARE, 2014, "Health and safety issues in REE mining and processing", An internal EURARE guidance report.http://www.eurare.eu/docs/internalGuidan ceReport.pdf

16- Heikal M.Th. S., REEs and RM-bearing minerals and their economic aspects. LAP LAMBERT Academic Publishing, Germany, 64 p (2014).

17- Heikal, M. Th. S., Mahmoud, K. R., ElSobky, T. and Top, G., "Toward Assessment the High Gamma Dose Levels and Relevant Human Health Impacts from Precambrian Granites, Na'wah Area, Yemen Republic", Inter. J. Env. Water, 5, 3, 1-12 (2016).
18- Bhattacharya, T., Madhavi Shankar V, Ram Mohan Reddy B., Thangavel, S., Sharma, P.K, "Radioactivity levels in the atomic mineral occurrences along Dharmapuri Shear zone in parts of Vellore, Krishnagiri, Dharmapuri and Salem districts of Tamil Nadu, India", Appl Radiat Isot.; 132:135-141. doi: 10.1016/j.apradiso.2017.11.028. Epub 2017 Dec 22 (2018).

19- Heikal,, M. Th. S. and Top G., "Assessment of Radioactivity Levels and Potential Radiation Health Hazards of Madsus Granites and Associated Dikes Nearby andAround Ruwisat Village, South Sinai, Egypt", Journal of African Earth

Sci. https://doi.org/10.1016/j.jafrearsci.2018.01.005 (2018).

20- Sinha, A. K., Glover, III L., "U/Pb systematics during dynamic metamorphism, a study from the Brevard fault zone", Contrib. Mineral Petrol 66, 305-310 (1978).

21- Wayne, D. M and Sinha, A. K., "Physical and chemical response of zircons to deformation", Contr. to Mineral. and Petrol, 98, 109-121. $\quad$ https://doi.org/10.1007/BF00371915 (1988).

22- Chen, C. J., Lin, Y. M., "Assessment of building materials for compliance with regulations of ROC", Environ. Int. 22, 221-226 (1996).

23- Abdel-Razek Y.A., Study of the Different Modes of the External Exposure to the Terrestrial Gamma Rays at Seila Area, Southeastern Desert, Egypt. InsightsMed Phys. 1:1 (2016).

24- Kapdan, E., Varinlioğlu, A. and Karahan, "Outdoor radioactivity and health risks in Balikesir, Northwestern Turkey", Radiation Protection Dosimetry, 1-9 (2012).

25- Al-Sharkawy, A., Hiekal, M. Th., Sherif, M. I. and Badran, H.M., Environmental assessment of gamma-radiation levels in stream sediments around Sharm El-Sheikh, South Sinai, Egypt. Journal of Environmental Radioactivity, 112, pp. 76-82 (2012).

26- Rangaswamy, D. R., Srinivasa, E., Srilatha, M. C. and Sannapp, A. J., "Measurements of terrestrial gamma radiation dose and evaluation of annual effective dose in Shimoga District of Karnataka State, India", Radiat Prot Environ, 38, 4, 154-159 (2015). 
27- Darwish, D. A. E., Abul-Nasr, K. T. M., ElKhayatt, A. M., , "The assessment of natural radioactivity and its associated radiological hazards and dose parameters in granite samples 28- Heikal, M. Th, S., Ghoneim, M. F., ElGaly, M. M., El-Dousky, B. T. and Sherif, M., "Environmental Assessment of Radiation Impacts on Sharm El-Sheikh Area, South Sinai, Egypt", Journal of KAU: Earth Sciences, 24,1,57-78 (2013).

29- OECD, Exposure to radiation from the natural radioactivity in building materials" Report by NEA Group of Experts of the OECD (Paris: Nuclear Energy Agency) (1979).

30- UNSCEAR (United Nations Scientific Committee on the Effects of Atomic Radiation), "Ionizing Radiation: Sources and Biological Effects" (New York: United Nations) (1982).

31- UNSCEAR, "United Nations Scientific Committee on the Effects of Atomic Radiation Sources and Effects of Ionizing Radiation", Report to the General Assembly, United Nations, New York (2008).

32- ICRP, "Protection against Radon-222 at home and at work", Issue 65. Ann 23 (2): 1-48 (1994).

33- CRC, 2003, CRC Handbook of Chemistry and Physics, (2003).

34- El-Kadi, M. B., Babourin, L. M. and Sarin, L., "Geological structure and mineral resources of Igla, Nuweibi and Abu Dabbab areas", Internal report, Geo. Surv. Egypt (1972).

35- Sabet, A. H., Chbanenko, V. and Tsogoev, V., "Tin-tungsten and rare metal mineralization in the Central Eastern Desert of Egypt", Geol. Surv. of Egypt, Cairo, Egypt, Ann. 3, 53-86 (1973).

36- Helba, H., Trumbull, R. B., Morteani, G., Khalil, S. O. and Arslan, A., "Geochemical and petrographic studies of Ta mineralization in the Nuweibi albite granite complex, Eastern Desert, Egypt. Miner. Deposits", 32,164-179 (1997).

37- Küster, D., "Granitoid-hosted Ta mineralization in the Arabian- Nubian Shield: ore deposit types, tectono-metallogenetic setting and petrogenetic framework", Ore Geol. Rev. 35,68-86 (2009).

38- Mohamed, A. M., "Immiscibility between silicate magma and aqueous fluids in Egyptian rare-metal granites: melt and fluid inclusions study", Arab J Geosci,15-25 (2012). from South Sinai, Egypt", J. Radiat. Res. Appl. Sci., 8, 17-25. doi: 10.1016/j.jrras.2014.10.003 (2015).

39- El Hadek, H. H., Mohamed, M. A., Bishara, W. W., El Habaak, G. H. and Ali, K. A., "Evolution of mineralizing fluids of greisens and fluorite veins, evidence from fluid inclusions ", Inter. J. Geophys. Geochem. 3, 5, 49-56 (2016). 40- Kröner, A., "Ophiolites and the evolution of tectonic boundaries in the Late Proterzoic Arabian Nubian Shield of NE Africa and Arabia. Precam", Res., 27, 277-300 (1985).

41- El-Tahawy, M. S. and Higgy, R. H., "Natural radioactivity in different types of bricks fabricated and used in the Cairo region", Applied Radiation Isotopes, 46, KU (1995).

42- Mantazul, I. C., Alam, M. N. and Ahmed, A. K. S., "Concentration of radionuclides in building and ceramic materials of Bangladesh and evaluation of radiation hazard", Journal of Radioanalytical and Nuclear Chemistry, 231, 117-122 (1998).

43- Cetin, E., Altinsoy N. and Orgun Y., "Natural radioactivity levels of granites used in Turkey", Radiation Protection Dosimetry, 151, No. 2, 299-305 (2012).

44- Zeghib, S., Aydarous, A. and Al-Qahtany, A., "Radiological Hazard Assessment of Raw Granites from Ranyah, KSA", Journal of Geoscience and Environment Protection, 4, 2438 (2016).

45- Gaafar, I., "Geophysical mapping, geochemical evidence and mineralogy for Nuweibi rare metal albite granite, Eastern Desert, Egypt", Open Journal of Geology, 4, 108-136 (2014).

46- Anjos, R. M., Juri Ayub, J., Cid A. S., Cardoso R. and Lacerda T., External gamma-ray dose rate and radon concentration in indoor environments covered with Brazilian granites. Journal of Environmental Radioactivity, 102, pp. 1055-1061 (2011).

47- UNSCEAR (United Nations Scientific Committee on the Effects of Atomic Radiation), "Sources, Effects and Risks of Ionizing Radiation (Report to the General Assembly with Scientific Annexes)" New York: United Nations (1993).

48- Beretka, J. and Mathew, P. J., "Natural radioactivity of Australian building materials, 
industrial wastes and by products", Health Phys. 48, 87-95 (1985).

49- Tufail, M., Javied, S., Akhtar, n., Hamid, T., "Natural radioactivity hazards of building bricks fabricated from saline soil of two districts of Pakistan", Journal of Radiological Protection, 27, pp. 481-492 (2007)

50- Avwiri, G. O., Osimobi, J. C. and Agbalagba, E. O., "Evaluation of radiation hazard indices and excess lifetime cancer risk due to natural radioactivity in soil profile of Udi and Ezeagu Local Government Areas of Enugu State, Nigeria" Compr. J. Earth Env. Sci. 1,1, 110 (2012).

51- Taskin, H. M., Karavus, P., Ay, A., Touzogh, S., Hindiroglu and Karahan, G., "Radionuclide concentration in soil and lifetime cancer risk due to the gamma radioactivity in Kirklareli, Turkey", J. Environmental radioactivity 100, 49-53 (2009).

52- Tukey, J., "Exploratory data analysis", Pearson, London (1977).
53- Trevisi, R., Risica D’Alessandro, M., Paradiso, D. and Nuccetelli, C., "Natural radioactivity in building materials in the European Union: a database and an estimate of radiological significance", J. Environ. Radioact. 105, 11-20 (2012).

54- Solak, S., Turhan, S., Uğur, F., Gören, E., Gezer , F. and Yegingil, Z., Yeğingil, I., "Evaluation of potential exposure risks of natural radioactivity levels emitted from building materials used in Adana, Turkey", Indoor Built Environ., 23,4,594-602 (2014).

55- Tanić, M. N., Momčilović, M. Z., Kovačević, J. R., Dragović, S. D. and Bačić, G. G., "Assessment of radiation exposure around abandoned Uranium mining area of Stara Planina Mt. ", Serbia Nuclear Tech. and Radiation Pub., 29,1,58-66 (2014).

56- Sabet, A.H., Tsogoev, V., Sarin, L.P., Azazi, S.A. Bedewi, M.A. and Ghobrial G.A., , TinTantalum deposit of Abu-Dabbab. Annals of the Geological Survey of Egypt 6, 93-117 (1976). 